Jurassic - Lower Cretaceous of the Danish Central Trough; - depositional environments, tectonism, and reservoirs

BY

OLAF MICHELSEN, NILS FRANDSEN, LISE HOLM, THORKILD FELDTHUSEN JENSEN, JENS JØRGEN M $\varnothing$ LLER \& OLE VALDEMAR VEJBAK

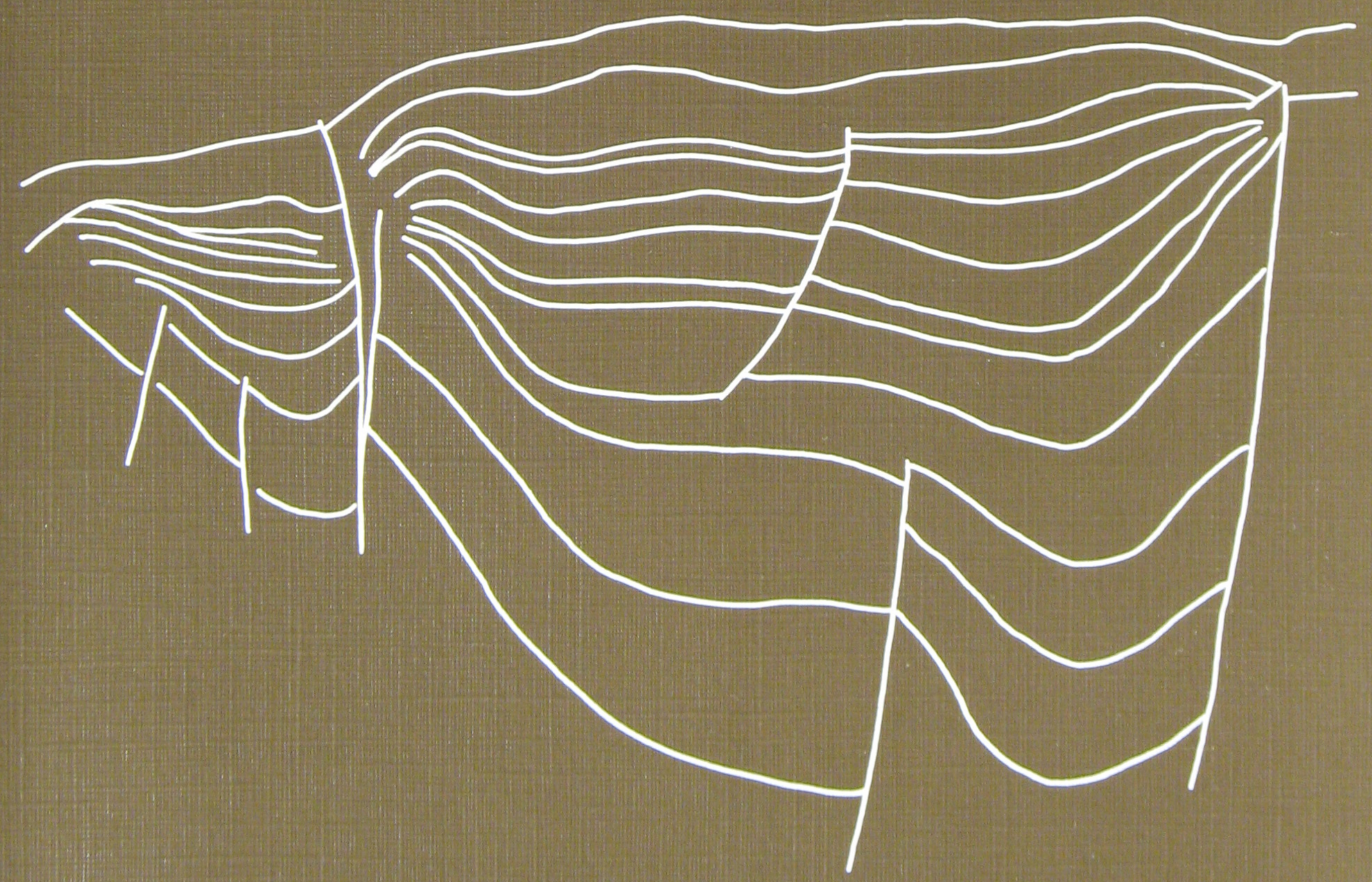

I kommission hos C. A. Reitzels forlag · København 1987 
DANMARKS GEOLOGISKE UNDERSØGELSE - SERIE A - NR. 16 MILJØMINISTERIET · Geological Survey of Denmark

\section{Jurassic - Lower Cretaceous of the Danish Central Trough; - depositional environments, tectonism, and reservoirs}

BY

OLAF MICHELSEN, NILS FRANDSEN, LISE HOLM, THORKILD FELDTHUSEN JENSEN, JENS JØRGEN MØLLER \& OLE VALDEMAR VEJBÆK

I kommission hos C. A. Reitzels forlag · København 1987 


\section{A contribution to \\ EFP-83 project: \\ Jurassic-Lower Cretaceous stratigraphy \\ and basin development of the Danish North \\ Sea sector}

Key words:

Danish North Sea, Central Trough, Jurassic,

Lower Cretaceous, basin development,

depositional environment,

tectonism, reservoir bodies.

Vignette:

East-west section through the Tail End Graben

DGU Serie A nr. 16

ISBN 87-421-0750-4

ISSN 0901-0270

Oplag: 1200

Tryk: AiO Tryk as, Odense

Tegning: Helle Zetterwall, Inge Martin-Legene, Gitte Nicolaisen

Dato: $15-12-1987$

Olaf Michelsen, Thorkild Feldthusen Jensen, Jens Jørgen Møller og Ole Valdemar Vejbæk; DGU, Thoravej 8, DK-2400 København NV.

Nils Frandsen; DOPAS, Agern Alle 24-26, DK-2970 Hørsholm,

Lise Holm; Energistyrelsen, Landemærket 11, DK-1119 København K.

Redaktion: Leif Banke Rasmussen

(C) Danmarks Geologiske Undersøgelse,

Thoravej 8, DK-2400 København NV 


\section{Tove Birkelund}

The present paper is dedicated to the late Professor Dr. TOVE BIRKELUND who until her death, June 24th 1986, participated with enthusiasm in the project work. With unfailing efforts Professor Birkelund criticized, supported and encouraged the members of the project group. 


\section{Preface}

The present paper is one of several reports issued as the result of a research project carried out by the Geological Survey of Denmark in cooperation with the Geological Institute at the University of Copenhagen. The project has been financed by special contributions from the Ministry of Energy for the period from August 1st 1983 to December 31st 1985.

The project was entitled "Jurassic - Lower Cretaceous stratigraphy and basin development of the Danish North Sea sector". It was decided to limit the study area to the Danish Central Trough, and effort has been concentrated on the Middle Jurassic, Upper Jurassic, and Lower Cretaceous.

The scope of the project was to coordinate analyses of the stratigraphy, facies development and burial history in order to create a basis for predicting possible occurrences of reservoir rocks. The following reports have been printed in 1986.

Frandsen, N.: Middle Jurassic deltaic and coastal deposits in the Lulu-1 well of the Danish Central Trough. Danm. geol. Unders., Ser. A, 9.

Hoelstad, T.: Palynology of the Middle Jurassic Lower Graben Sand Formation of the U-1 well, Danish Central Trough. Danm. geol. Unders., Ser. A, 14.

Hoelstad, T.: Palynology and palynofacies analyses of the Middle Jurassic to Lower Cretaceous in the Danish Central Trough. Danm. geol. Unders., Internal report.
Jensen, T.F., Holm, L., Frandsen, N. \& Michelsen, O.: Jurassic - Lower Cretaceous lithostratigraphic nomenclature for the Danish Central Trough. Danm. geol. Unders., Ser. A, 12.

Møller, J.J.: Seismic structural mapping of the Middle and Upper Jurassic in the Danish Central Trough. Danm. geol. Unders., Ser. A, 13.

Vejbæk, O.V.: Seismic stratigraphy of the Lower Cretaceous in the Danish Central Trough. Danm. geol. Unders., Ser. A, 11.

The following reports (including the present one) will be issued in 1987:

Heilmann-Clausen, C.: Lower Cretaceous dinoflagellate biostratigraphy in the Danish Central Trough.

Michelsen, O., Frandsen, N., Holm, L., Jensen, T.F., Møller, J.J. \& Vejbæk, O.V.: Jurassic - Lower Cretaceous of the Danish Central Trough; - depositional environments, tectonism, and reservoirs.

Poulsen, N.: Callovian (Jurassic) to Ryazanian (Cretaceous) dinoflagellate biostratigraphy of the Danish Central Trough.

Thomsen, E.: Lower Cretaceous calcareous nannofossil biostratigraphy in the Danish Central Trough.

DGU, 30th November $1986 \quad$ Olaf Michelsen 


\section{Contents}

Abstract $\ldots \ldots \ldots \ldots \ldots \ldots \ldots \ldots \ldots \ldots \ldots$

Introduction $\ldots \ldots \ldots \ldots \ldots \ldots \ldots \ldots \ldots \ldots \ldots$

Structural framework . . . . . . . . . . . . 12

Highs $\ldots \ldots \ldots \ldots \ldots \ldots \ldots \ldots \ldots \ldots \ldots$

Lows ........................ 14

Intermediate areas $\ldots \ldots \ldots \ldots \ldots \ldots \ldots \ldots$

Depositional evolution ................. 19

Early Jurassic. . . . . . . . . . . . . . . . . . 19

Middle Jurassic . . . . . . . . . . . . . . 21

Distribution of the Middle Jurassic . . . . . . . . 22

Regional development in the Middle Jurassic . . 22

Late Jurassic ................... 23
Basin development in the Late Jurassic . . . . . 28

Early Cretaceous.................. 29

Basin development in the Early Cretaceous ... 37

Reservoir sediments .................. 39

Fluvial, deltaic and marginal marine sands ... 39

Shallow marine sands.............. 40

Deeper marine sands ............... 41

Pelagic carbonates. . . . . . . . . . . . . 42

Concluding remarks $\ldots \ldots \ldots \ldots \ldots \ldots \ldots \ldots \ldots 43$

Acknowledgements................ 43

References ...................... 44 


\section{Abstract}

A revised model for the Jurassic - Early Cretaceous basin development in the Danish Central Trough is described on the basis of new studies of the bio- and lithostratigraphy and sedimentological and seismic data.

The trough has been subdivided into a number of areas, each characterized by specific structural evolution.

Middle Jurassic fluvio-deltaic and coastal sands follow the mid Cimmerian unconformity and probably cover large parts of the trough. Right-lateral movements, initiated during the Late Jurassic along WNWESE trending faults, caused fault controlled basin subsidence. The Jurassic and early Early Cretaceous sedimentation was dominated and characterized by clay. More than $4000 \mathrm{~m}$ of clay were deposited. Organic carbon rich clays were deposited from the Kimmeridgian until the Late Ryazanian, when deposition of organic carbon poor sediments under oxygenated conditions commenced. During the Late Jurassic transgression coastal sands were deposited along tectonically quiet basin margins. Sands deposited from density currents accumulated along tectonically active margins at the Jurassic-Cretaceous transition. More centrally in the basins, more distal turbidite deposits of Late Jurassic age may be present.

Early Cretaceous basin expansion caused by elevation of the sea-level led to decreasing siliciclastic deposition rates and hence to more calcareous sediment types. Contemporaneously basin subsidence decreased. At mid Hauterivian time the importance of differential subsidence governed by left-lateral transtensional wrenching along NNW-SSE trending faults decreased. This change was accompanied by a mild inversion controlled by NNW-SSE directed right-lateral transpression, heralding regional subsidence. Following this inversion chalk was deposited in almost the entire trough area. Later, during the Barremian and Aptian anoxia in the basin caused deposition of marls rich in organic carbon, followed by marls deposited under oxygenated conditions during the Albian transgression.

The distribution and character of possible reservoir bodies are discussed. 


\section{Introduction}

Since the late 1960s hydrocarbon exploration has yielded a large amount of information about the $\mathrm{Da}$ nish Central Trough (fig. 1). Rasmussen (1974, 1978) and Michelsen (1978a) presented biostratigraphic subdivisions of the Jurassic and the Lower Cretaceous in individual well profiles. Birkelund et al. (1983) discussed the stratigraphy around the Jurassic-Cretaceous transition, and the sedimentology of Middle and Upper Jurassic sandstones was interpreted by Koch (1983).

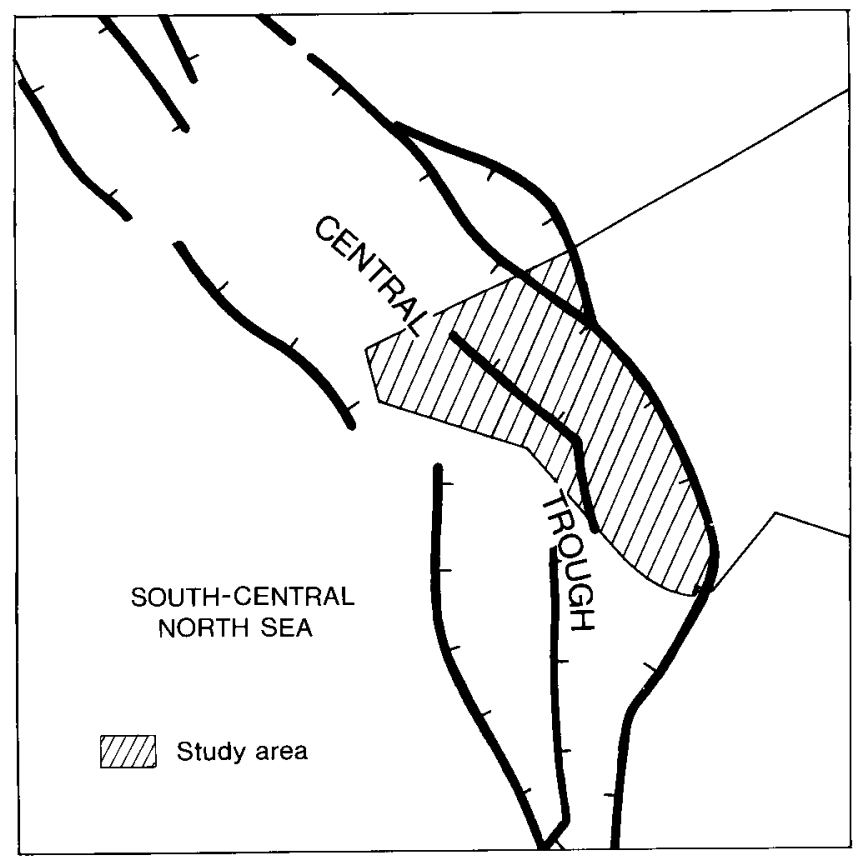

Fig. 1: Regional structural outline of the south-central North Sea with emphasis on the Danish sector.

The subsidence history of the Jurassic sequence was outlined by Holm (1983) and Hansen \& Mikkelsen (1983), while the general structural development of the Danish Central Trough was discussed by Michelsen \& Andersen (1983) and by Gowers \& Sæbøe (1985). A detailed and comprehensive account, dealing with a wide range of geological aspects of the Danish Central Trough, was given by Michelsen (1982).

The Jurassic - Lower Cretaceous sequence of the Danish Central Trough has been the subject of a multidisciplinary investigation carried out during the years 1983-1985 by the project group mentioned in the preface. Biostratigraphic analyses are based primarily on dinocyst stratigraphy (Heilmann-Clausen 1987, Hoelstad 1986a and b, Poulsen 1987). Studies of the sediments have led to a sedimentologic interpretation of the sand-dominated, Middle Jurassic sequence drilled in the Lulu-1 well (Frandsen 1986). The structural evolution of the Central Trough has been analysed on the basis of new seismic data and a new subdivision into smaller structural units has been established (Møller 1986 and Vejbæk 1986).

Koch et al. (1982) and Hansen \& Buch (1982) present informal lithostratigraphic schemes for the Danish Central Trough. The former paper deals with the Jurassic sequences and the latter with the Lower Cretaceous. New well information, combined with biostratigraphic studies by Heilmann-Clausen (1987) and Thomsen (1987), with seismic studies by Møller (1986) and Vejbæk (1986) and with lithostratigraphic studies by Hesjedal \& Hamar (1983) and Vollset \& Doré (1984) have led to a revision of the earlier lithostratigraphic schemes by Jensen et al. (1986). Figure 2 shows the new, formal lithostratigraphic units compared with the previous, partly informal ones, and figs. 3 and 4 show regional correlations.
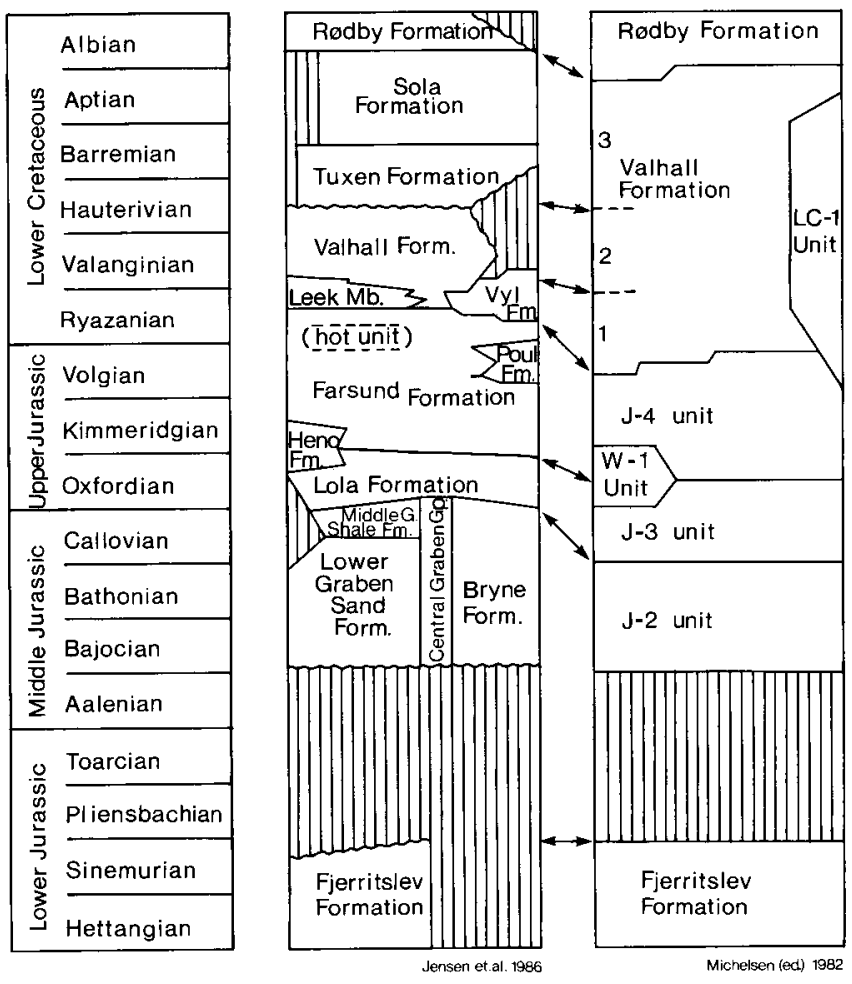

Fig. 2: Lithostratigraphy for the Jurassic and Lower Cretaceous of the Danish Central Trough. Comparison with the informal lithostratigraphy of Koch et al. (1982) and Hansen \& Buch (1982). 
During the work leading to these publications it became clear that a certain amount of information and ideas could not be included in the above mentioned papers. Especially, interpretation of the development of the depositional environments could not be included. Their relationship to the structural evolution is therefore the main topic of the present paper. Analyses of stratigraphy, facies development and burial history during the Jurassic and Early Cretaceous have been coordinated in order to create a basis for the prediction of possible occurrences of reservoir rocks. Furthermore, the reservoir properties of reservoir units are treated in a special chapter.

JURASSIC LITHOSTRATIGRAPHIC CORRELATION CHART

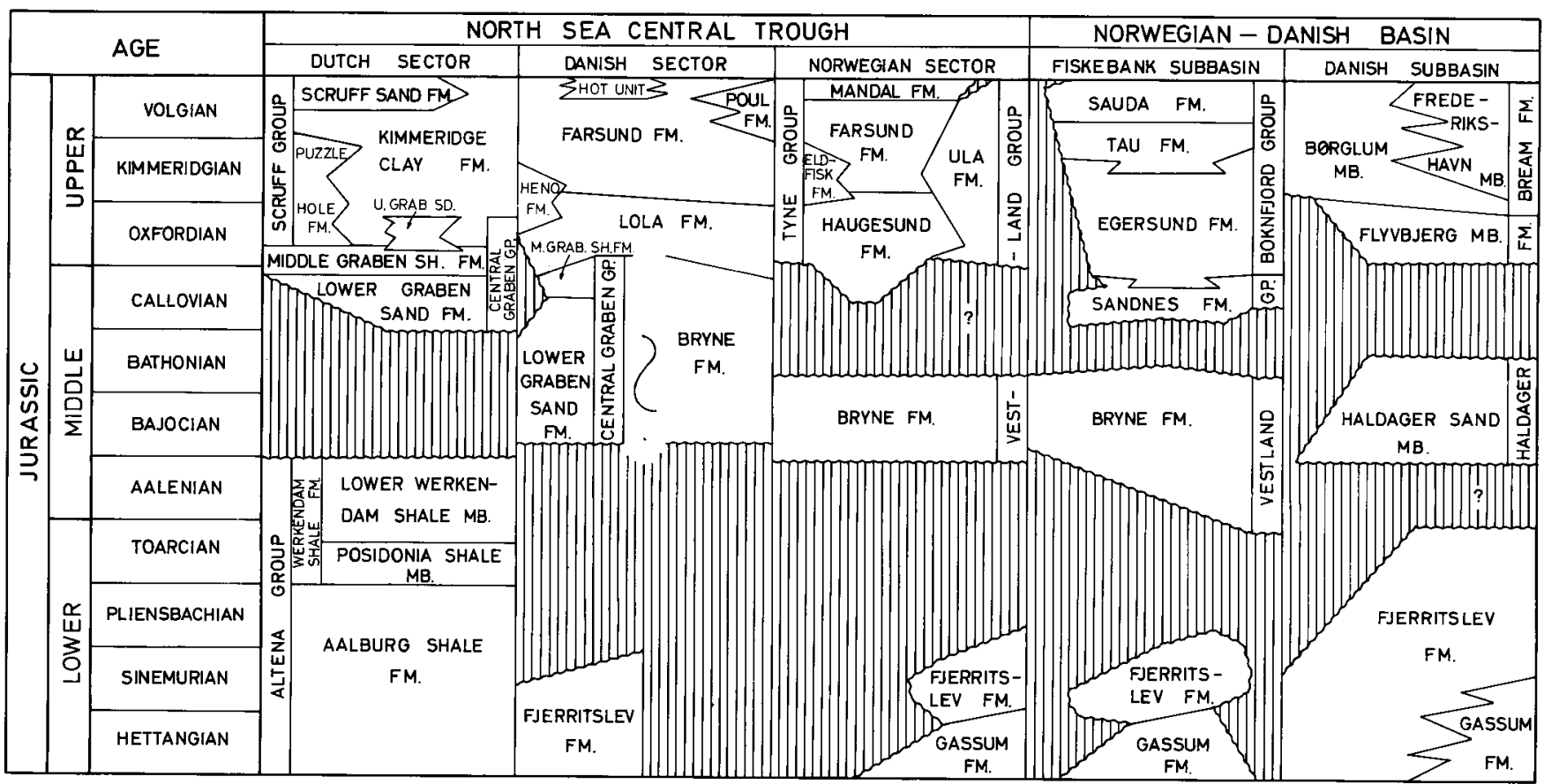

Fig. 3: Jurassic lithostratigraphy in the Danish Central Trough and adjacent areas.

LOWER CRETACEOUS LITHOSTRATIGRAPHIC CORRELATION CHART

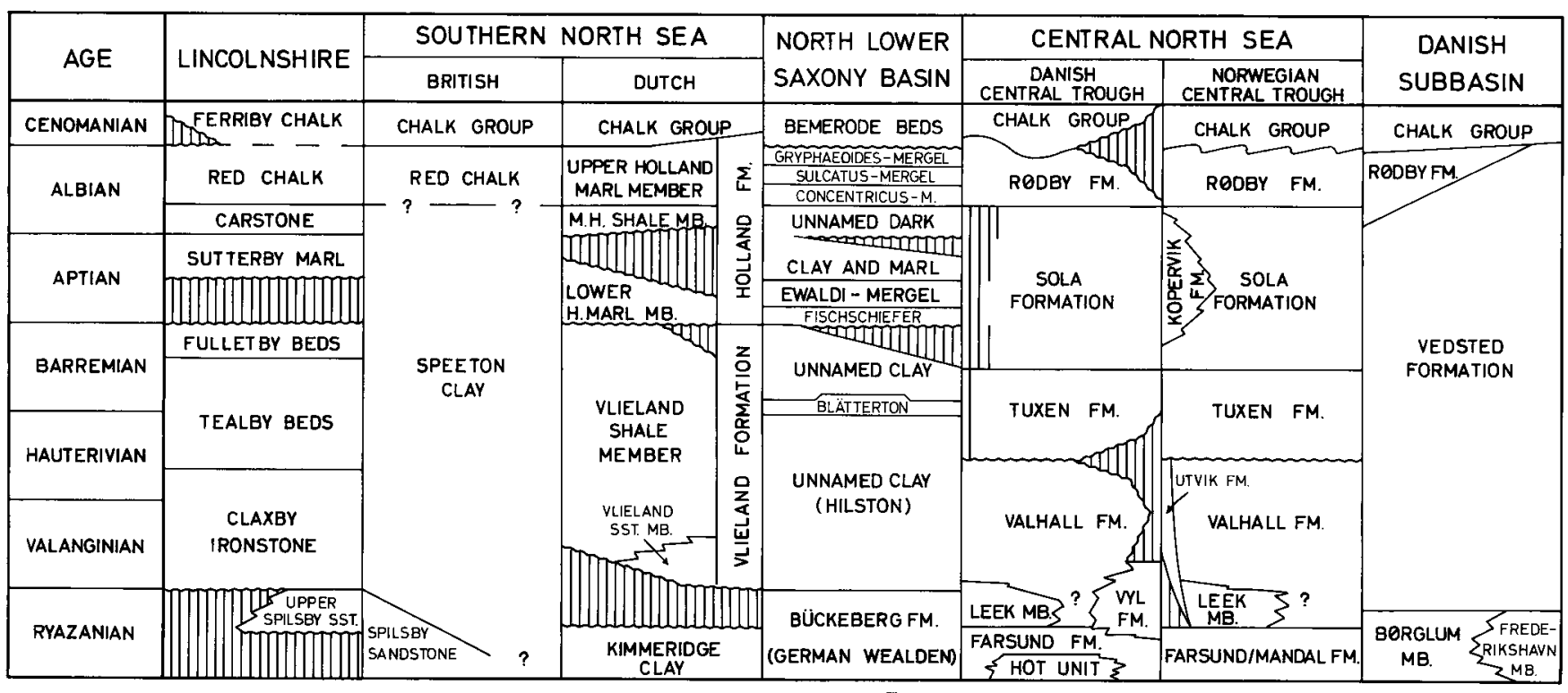

Fig. 4: Lower Cretaceous lithostratigraphy in the Danish Central Trough and adjacent areas. 


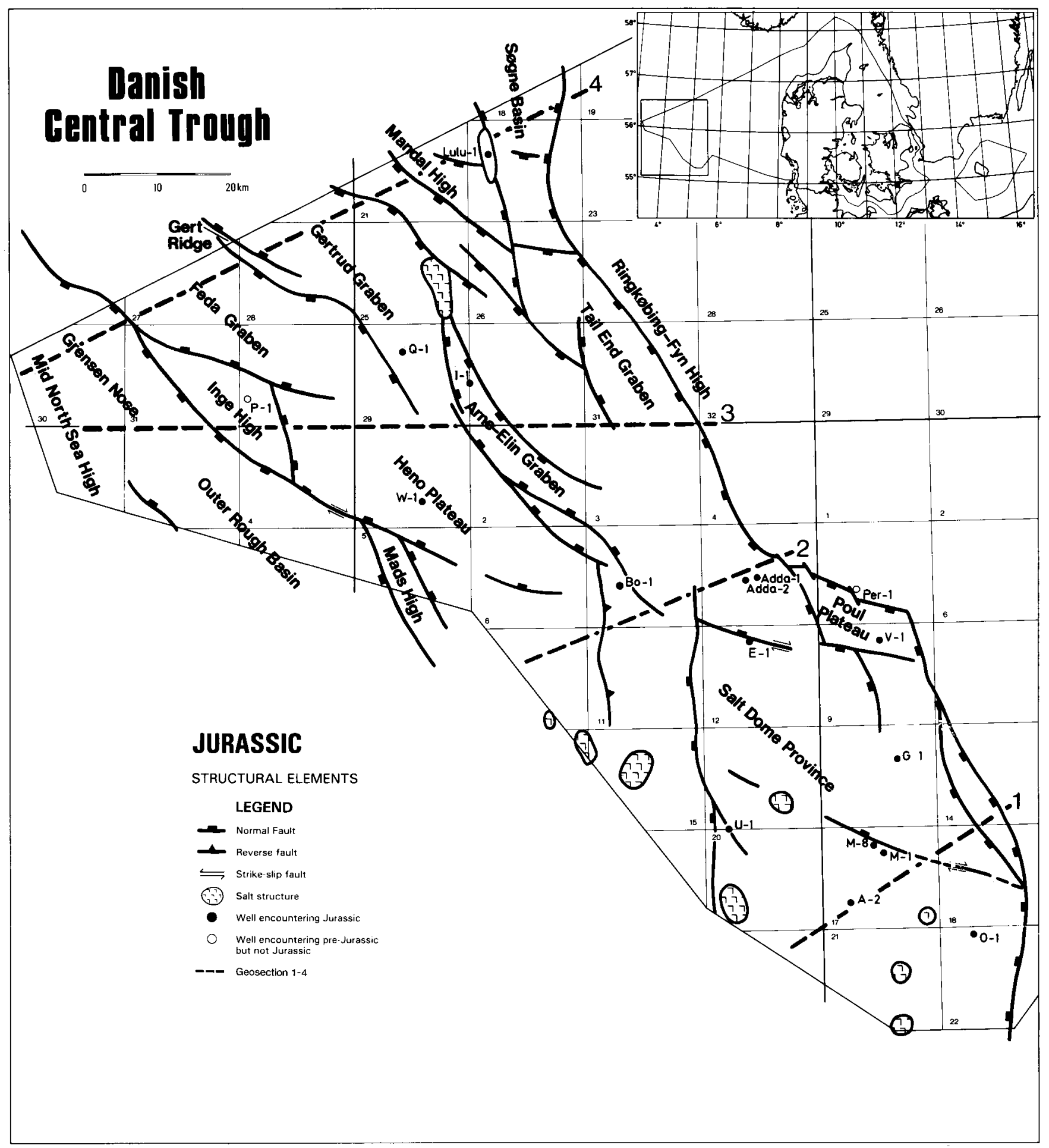

Fig. 5: Jurassic structural outline of the Danish Central Trough, including well location. Locations of geosections are also shown. 
The Central North Sea Highs comprise a complex of structural highs trending east-west across the North Sea which came into existence during the Early Permian (Ziegler 1982). As a prelude to the opening of the North Atlantic, rifting occurred at various places in the North Sea region (Eynon 1981). One result of the rifting was the formation of the Central Trough separating the Mid North Sea High from the Ringkøbing-Fyn High. Differential subsidence caused by block faulting and rifting controlled the development of the trough during the Jurassic. This tensional regime was gradually replaced by a compressional regime during the Cretaceous.

The structural picture of the Danish Central Trough in figs. 5 and 6 is characterized by a complex pattern of highs, lows and intermediate areas (Gowers \& Sæbøe 1985, Møller 1986, Vejbæk 1986).

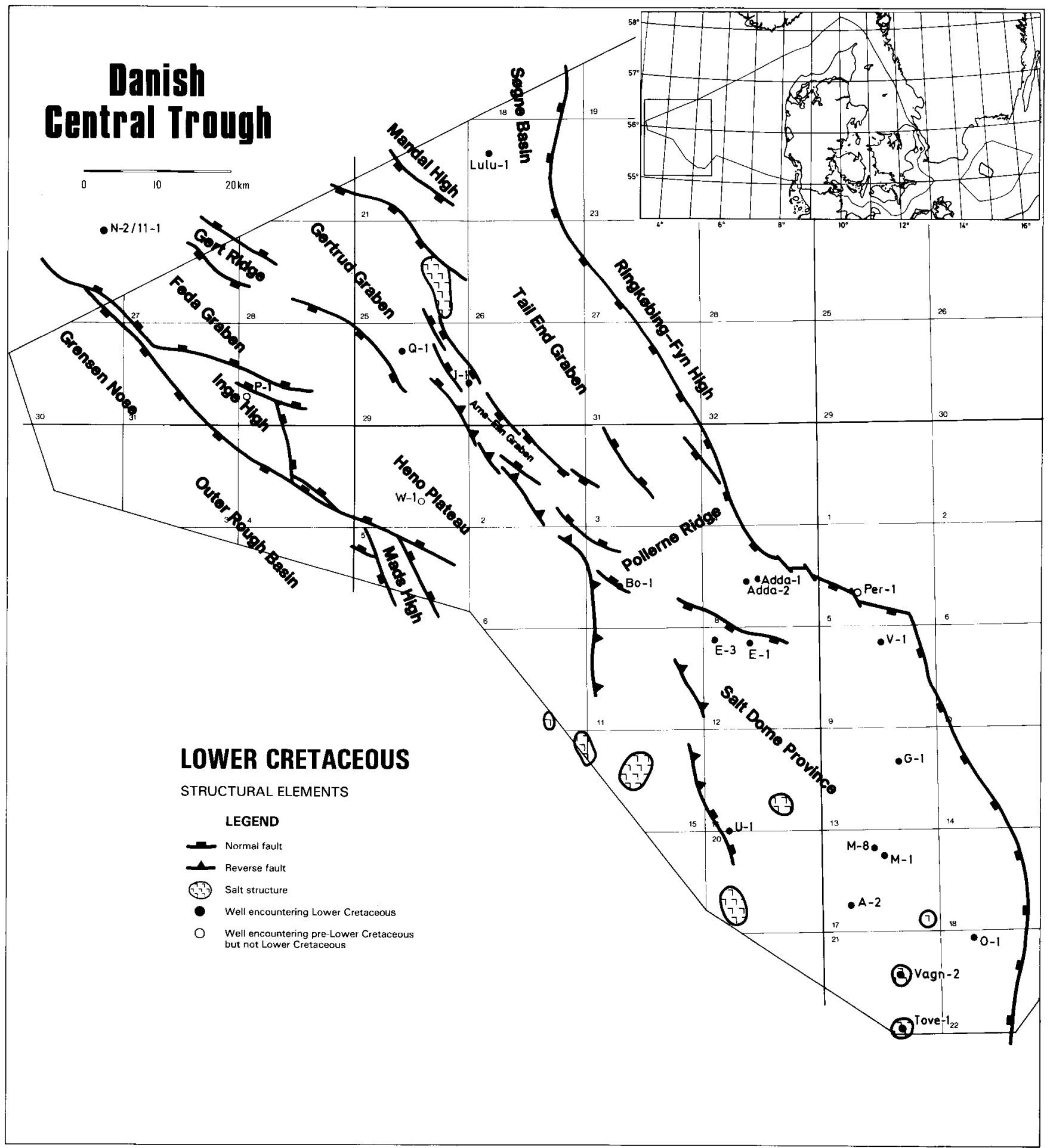

Fig. 6: Lower Cretaceous structural elements of the Danish Central Trough, including well locations. 


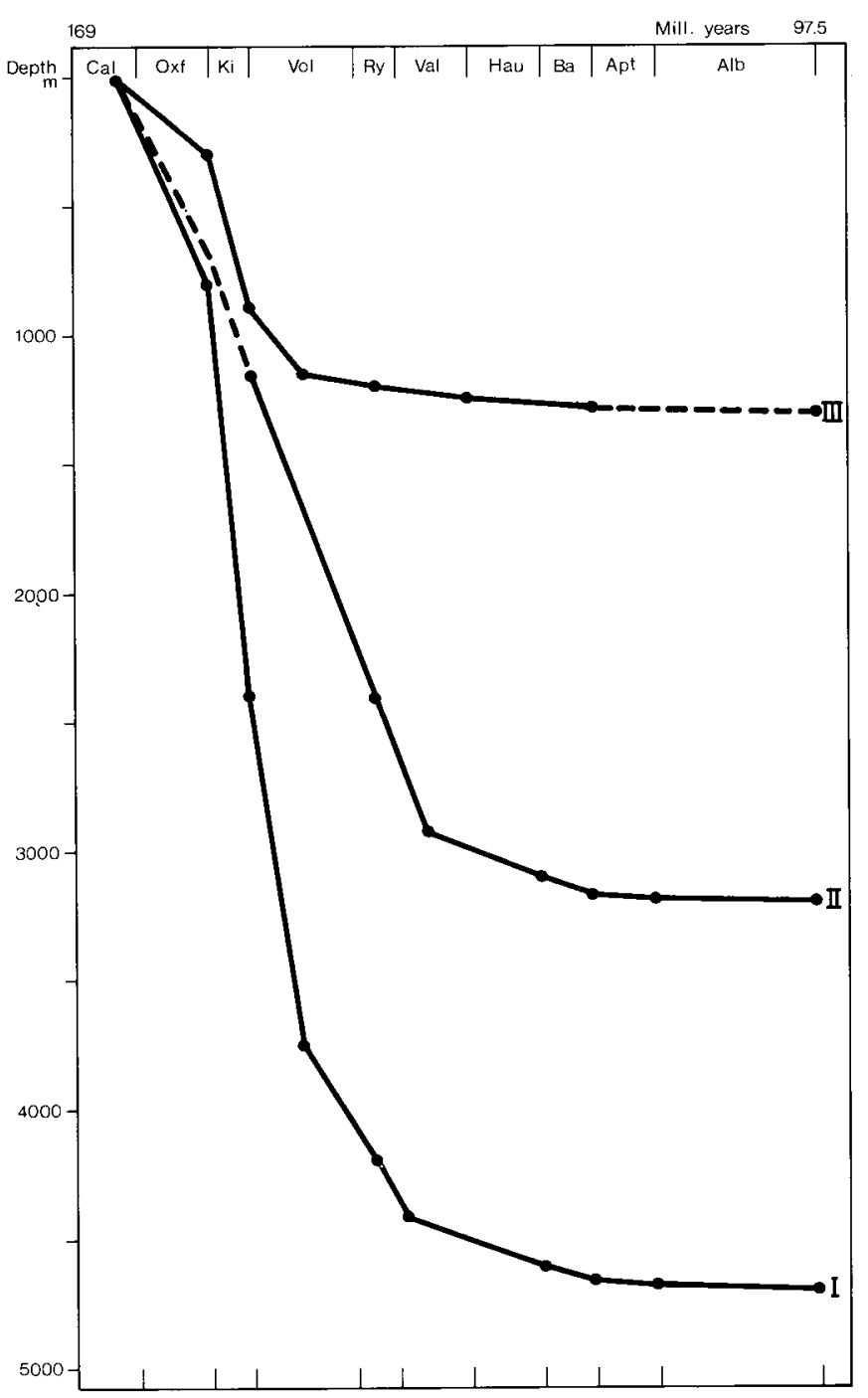

Fig. 7: Burial diagrams for three different area types in the Central Trough, constructed on the basis of seismic isopach maps, internal Upper Jurassic reflectors and biostratigraphic subdivision of relevant wells. Compaction effects have not been considered. Curve I represents areas with near maximum sedimentation rate in the Late Jurassic and mean sedimentation rate in the Early Cretaceous. A point in the eastern part of the Tail End Graben has been chosen as a reference point. Curve II represents areas with rather high Late Jurassic sedimentation rate and near maximum Early Cretaceous sedimentation rate. A point in the southwestern part of the Feda Graben has been used as reference point. Curve III represents areas with low to moderate sedimentation rates in the Late Jurassic and low sedimentation rate in the Early Cretaceous. A point in the southwestern part of the Salt Dome Province has been used as reference point. The geochronological scale is based on Kent \& Gradstein (1985).

\section{Highs}

On the highs, the Precambrian or Caledonian basement is found at relatively shallow depths and Jurassic Lower Cretaceous sequences are thin or absent.

Two major highs, the Ringkøbing-Fyn High and the Mid North Sea High, define the eastern and western margins respectively of the Danish Central Trough (fig.
5). The former is bounded towards the trough by a system of well defined, basement attached, normal faults, while the latter is characterized by a gradual transition via intermediate highs to the deeper lying basins of the trough.

In the western part of the trough, two smaller highs, the Inge and Mads Highs, make up what was formerly known as the Dogger High (Michelsen \& Andersen 1983). They are separated by a WNW-ESE trending fault zone which had a right-lateral strike-slip component during the Late Jurassic (Møller 1986). This fault zone apparently became inactive during the Early Cretaceous. It is the major tectonic feature in this part of the trough and forms part of the boundary between the highs and the surrounding areas, while elsewhere the boundaries of the highs are characterized by gradual transitions via minor normal faults. Structural inversion during the Late Cretaceous has overprinted, and to a considerable degree complicated, this tectonic pattern.

The Mandal High extends from the Norwegian into the Danish sector where it forms the western edge of the Søgne Basin.

\section{Lows}

Relatively high rates of sedimentation and subsidence during the Jurassic are characteristic for the lows (fig. 7). Their subsidence was uniform during the Middle and early Late Jurassic, whereas in the late Late Jurassic there was remarkably increased subsidence in the Tail End Graben and the Feda Graben relative to the other lows. This subsidence is related to the rightlateral strike-slip movements mentioned above. Tectonic activity and sedimentation rates decreased markedly during the Early Cretaceous.

Major lows extend along the fault system bounding the Ringkøbing-Fyn High and are typically developed as half-grabens with their major Jurassic subsidence close to these eastern boundary faults. Intermediate fault blocks are typified by the Poul Plateau where the timing of fault movements is indicated by a hiatus between Triassic and early Late Jurassic sediments (fig. $8)$.

The most typical half-graben development is found in the Tail End Graben where the Middle to Upper Jurassic sequence is more than $4000 \mathrm{~m}$ thick (figs. 9 and 10 ). The western boundary of this graben was rather vaguely defined by a more or less gradual transition to the Heno Plateau for most of the Jurassic. The main subsidence took place at Kimmeridgian-Volgian times (fig. 7) and during this period, a narrow graben, the Arne-Elin Graben, developed at the western margin. The opening of this graben was probably linked to movements along inferred strike-slip WNW-ESE faults located at the southern end of the Tail End Graben and along the southern end of the Søgne Basin. The struc- 


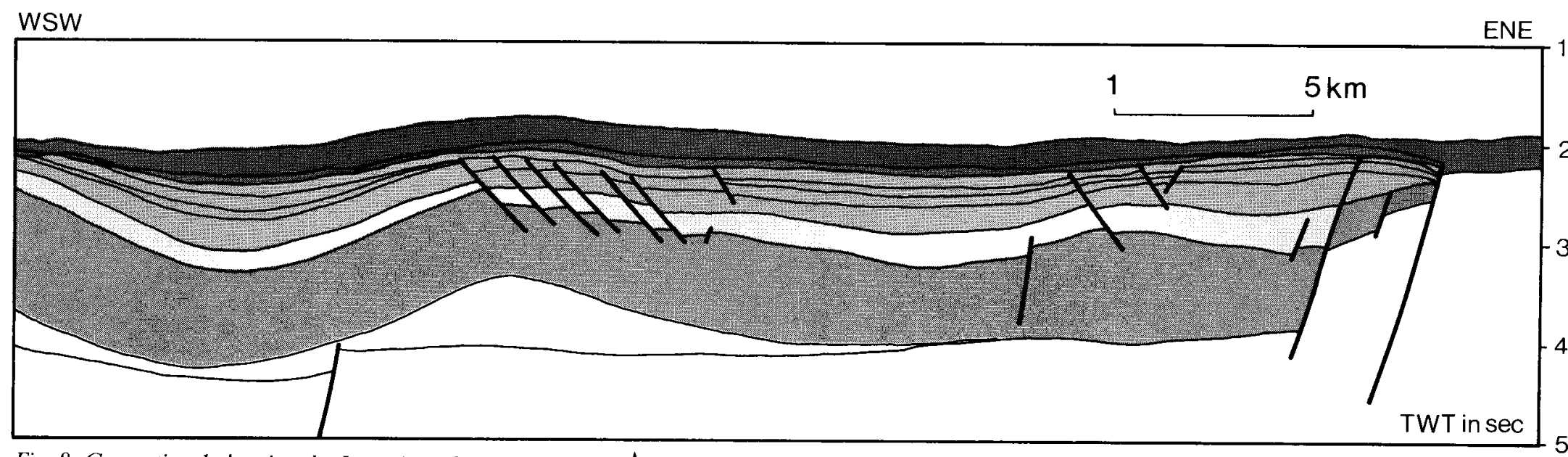

Fig. 8: Geosection I showing the Jurassic and Lower Cretace- A

ous sequences across the Salt Dome Province. For location see

fig. 5 , and for legend fig. 9

Fig. 9: Geosection 2 showing the Jurassic and Lower Cretaceous sequences across the southern part of the Tail End Graben. $\checkmark$ For location see fig. 5.

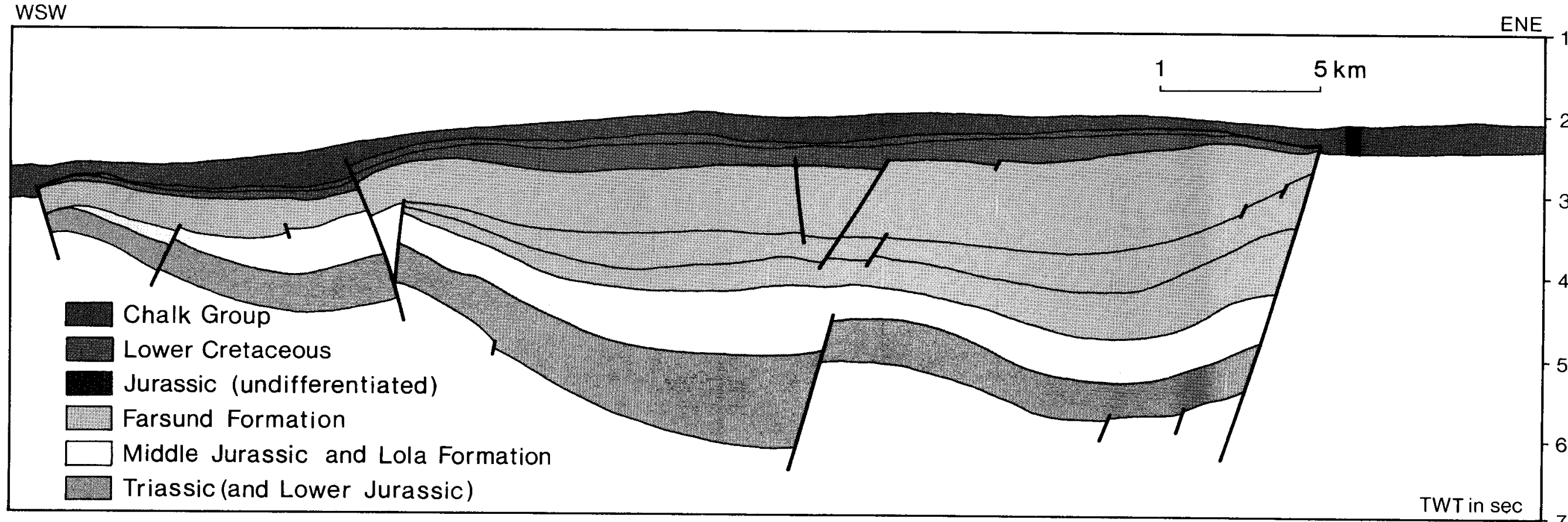



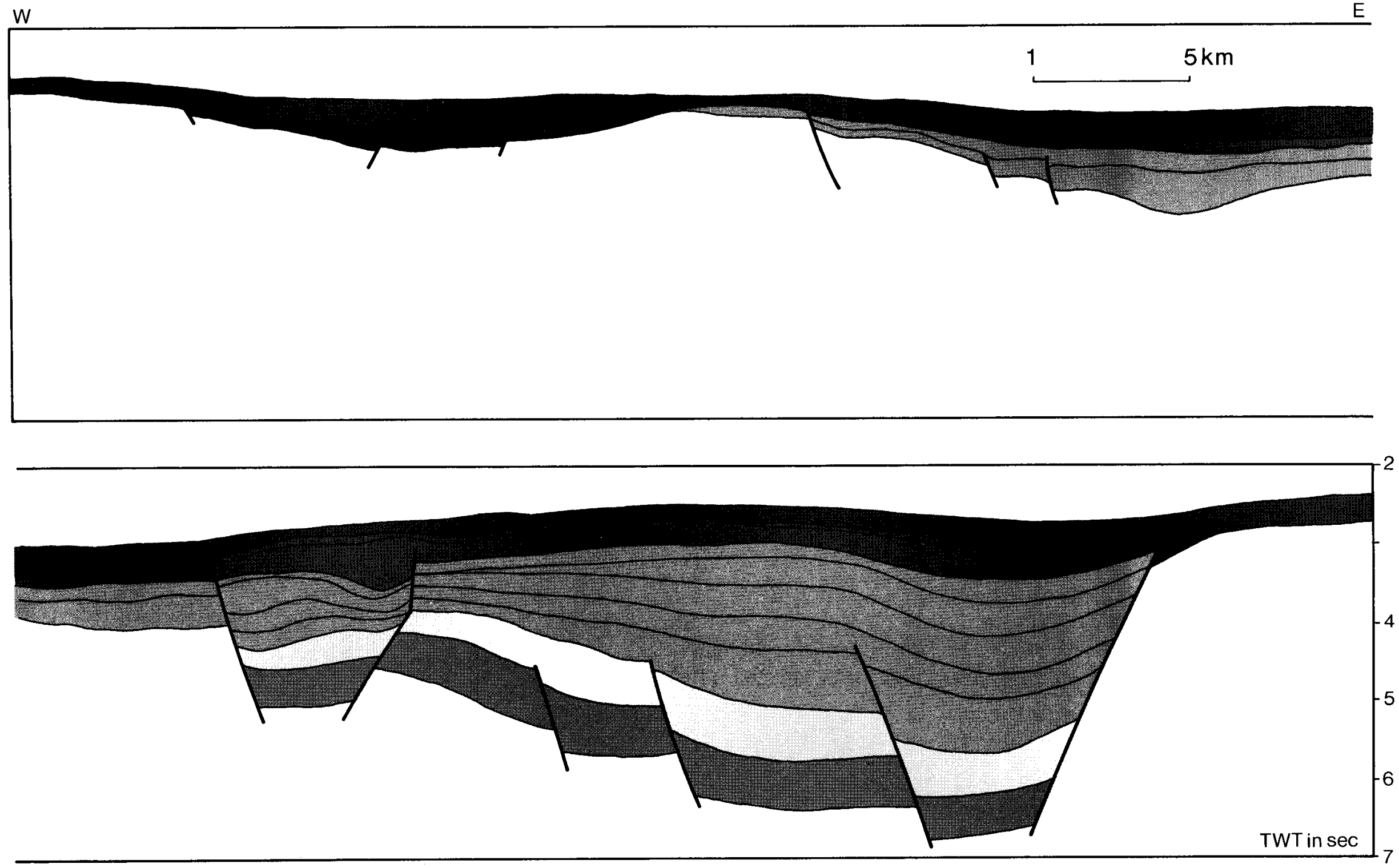

Fig. 10: Geosection 3 showing the Jurassic and Lower Cretaceous sequences across the central part of the Danish Central Trough. For location see fig. 5, and for legend fig. 9. 


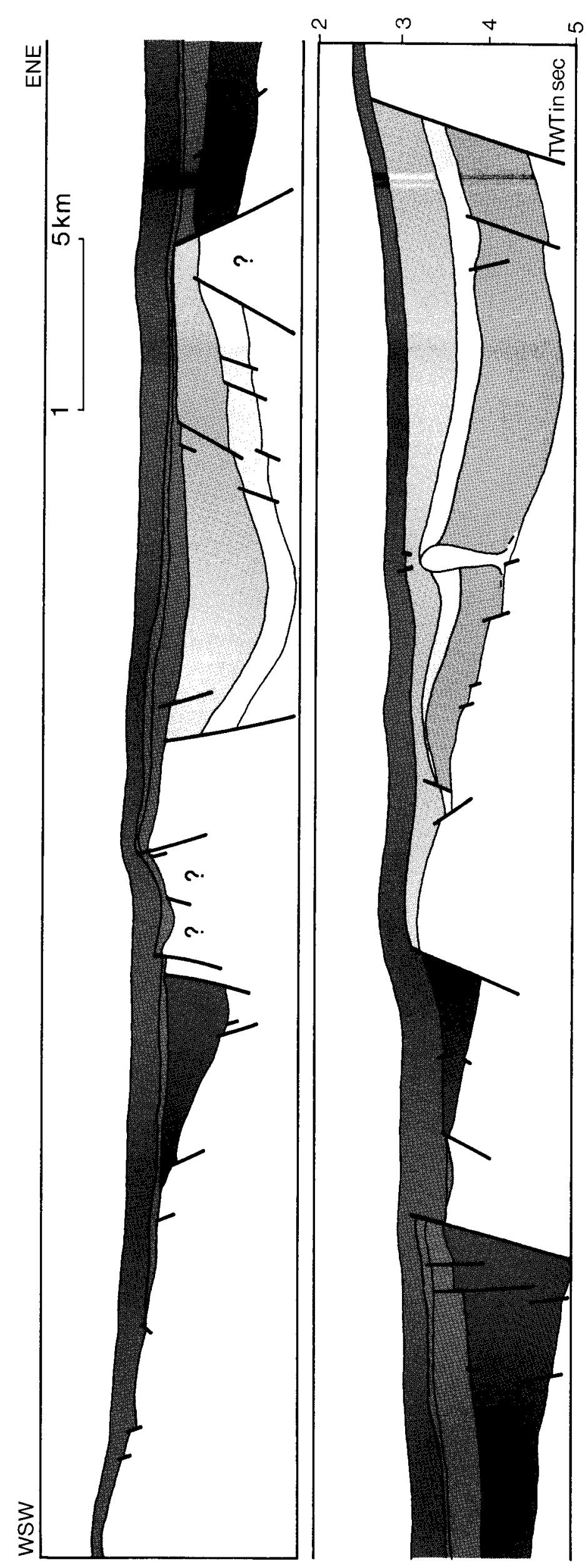

ture and subsidence patterns in the Arne-Elin Graben were governed by strike-slip movements along the conjugated NNW-SSE fault direction. Movement along the bounding faults of the graben was inverted during the Late Cretaceous.

To the north the Tail End Graben is bounded by the Søgne Basin. The boundary is defined by the extension to the southeast of the southwestern boundary fault of the Mandal High (fig. 5). The Tail End Graben narrows and the Jurassic and Lower Cretaceous sequences wedge out between the Gertrud Graben and the Mandal High - Søgne Basin area. South of the Tail End Graben there is a gradual transition to the Salt Dome Province which is characterized by lower subsidence rates during the Volgian (fig. 7) than the Tail End and Feda Grabens and by the presence of salt structures. Salt movements to a certain degree influenced deposition in the Salt Dome Province and the half-graben development is less distinct than in the Tail End Graben (fig. 8). The Middle to Upper Jurassic sequence therefore only shows minor thickness variations from the east to the west whereas the transition to the Tail End Graben is marked by a distinct increase in thickness going from south to north.

During the Early Cretaceous a small ridge (the Pollerne Ridge) emerged. The result was a separation of the northern part of the Tail End Graben from the southernmost part. This southernmost part subsequently exhibited the same subsidence pattern as the Salt Dome Province and it is hence included in this basin (compare figs. 5 and 6). The depositional rates were of the same order of magnitude north and south of the Pollerne Ridge.

The Søgne Basin is part of what was previously known as the Northern Salt Dome Province (Michelsen \& Andersen 1983). Like the Tail End Graben, it is a well-defined half-graben (fig. 11) but it has a fairly thin upper Upper Jurassic sequence reflecting relatively limited subsidence during the Late Jurassic. Halokinesis has had some influence on Jurassic sedimentation. The basin was probably elevated late in the Late Jurassic and erosion is assumed to have taken place during the Early Cretaceous.

Two half-grabens, the Feda Graben and the Gertrud Graben, are outlined in the northwestern part of the Danish Central Trough. They are separated by the narrow Gert Ridge and have a more or less symmetric configuration around the ridge. The Gertrud Graben had its main subsidence to the northeast, close to the Tail End Graben, whereas the main subsidence in the Feda Graben moved from the south, close to the Inge High, to a more central position in the graben during the Jurassic. The two grabens were apparently connected until the Volgian when new faults divided this basin and caused differential subsidence of the two grabens, bringing the Gert Ridge into existence. During the late Late Jurassic and Early Cretaceous the 
subsidence rate of the Feda Graben became much greater than that of the Gertrud Graben.

\section{Intermediate areas}

The Heno Plateau is a rather complex feature bounded by faults towards the Arne-Elin Graben and the Inge and Mads Highs (fig. 10) and it has transitional and poorly defined boundaries to the Feda, Gertrud and Tail End Grabens. The Jurassic sequence is less than
$1000 \mathrm{~m}$ thick and Middle Jurassic sediments appear to be absent (no Middle Jurassic deposits are seen in the W-1 well).

Two areas of intermediate subsidence, the Grensen Nose and the Outer Rough Basin, are defined in the westernmost part of the Danish Central Trough. They flank the Mid North Sea High and probably formed part of the high until the Late Jurassic. They have a thin Jurassic sequence and mainly developed during the Cretaceous. Interpretation suffers from a lack of well data and direct seismic ties to the east. 


\section{Early Jurassic}

In the Danish Central Trough the clay-dominated Fjerritslev Formation is found only in the Salt Dome Province (the M-8, O-1 and U-1 wells) where it is of Hettangian to Late Sinemurian age and has thicknesses less than $200 \mathrm{~m}$ (Michelsen 1978a). In the well sections, the formation is separated from the underlying, also clayey, Rhaetian Winterton Formation by a hiatus. Seismic profiles show truncation of seismic reflectors at anticlinal structures indicating an unconformity at the base of the Fjerritslev Formation (Andersen et al. 1982).

The age of the Winterton Formation appears to correspond to that of the Vinding Formation of the Danish Subbasin (Bertelsen 1980). The younger, although still Rhaetian, Gassum Formation seems to have no timeequivalent in the Salt Dome Province (Michelsen \& Andersen 1983).

The hiatus thus indicated was probably caused by the early Cimmerian tectonic phase which may have led to erosion removing much of the Winterton Formation (Andersen et al. 1982).

The hiatus does not appear to correspond to any important change in sedimentation. The Winterton Formation is interpreted as a marine deposit in a coas- tal environment (Bertelsen 1980) and the Fjerritslev Formation was mainly deposited from suspension in an open marine environment with upwards diminishing terrestrial influence as indicated by an upwards decreasing content of siltstone beds (Koch et al. 1982). The Fjerritslev Formation is compatible with the general eustatic sea-level rise interpreted for the Early Jurassic (Hallam 1981).

Outside the Salt Dome Province, the Fjerritslev Formation occurs in its type area, the Danish Subbasin (Michelsen 1978b), where it has an age span from the Hettangian to the Toarcian, possibly ranging into the Aalenian (Michelsen et al. 1984). Contemporaneous clay sequences in the Norwegian sector of the North Sea are included in the formation (Vollset \& Doré 1984). Deposits with comparable lithology and age are found further north in the Norwegian and British sectors (Dunlin Group, Vollset \& Doré 1984), in the southern part of the British sector (Lias Group, Rhys 1974) and in the Dutch sector (Aalburg Shale Formation, Posidonia Shale Member, NAM \& RGD 1980). These deposits show that the Early Jurassic sea-level rise was reflected by widespread sedimentation of marine clays in the North Sea region.

In the Danish Central Trough outside the Salt Dome Province and in most of the Norwegian Central Trough

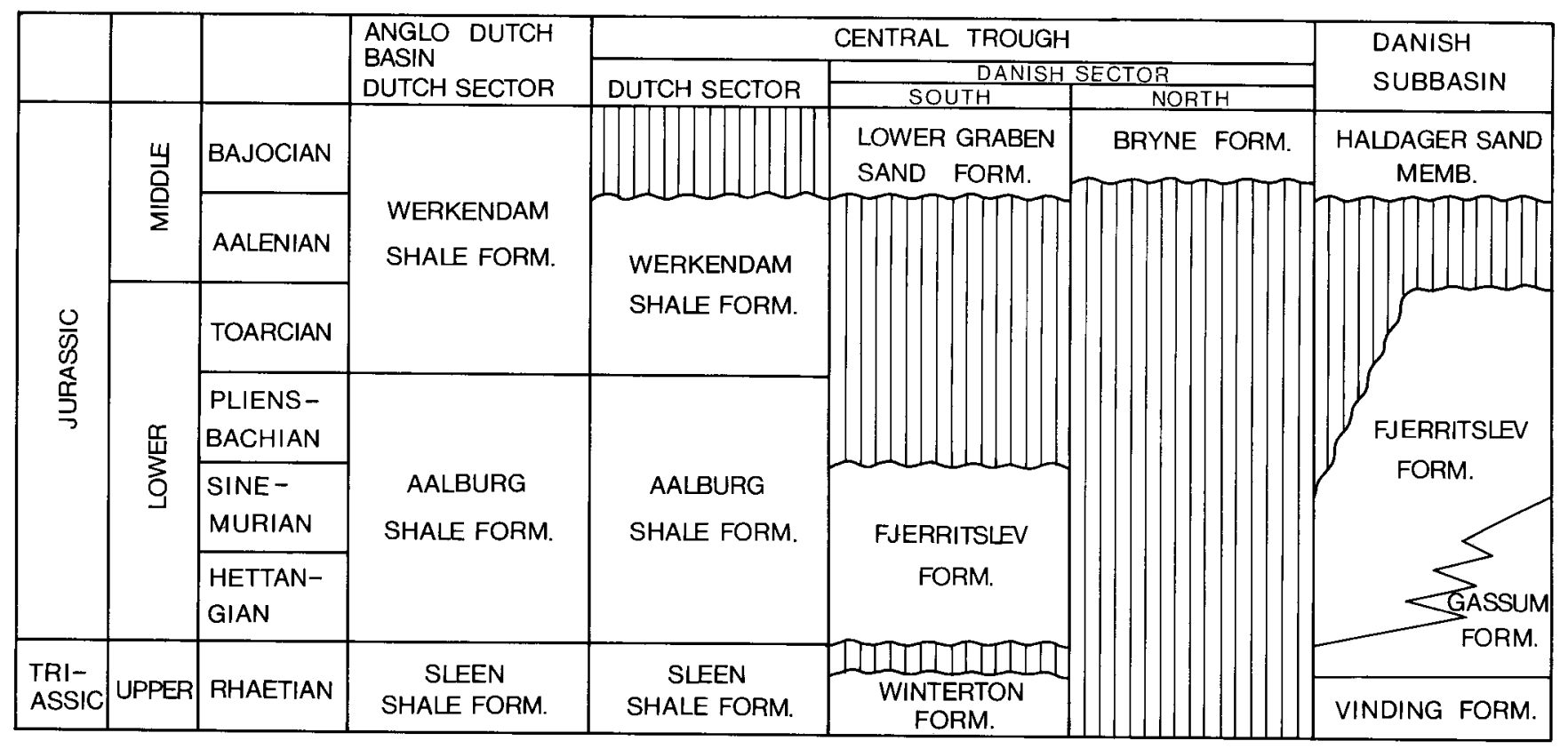

Fig. 12: Lithostratigraphic correlation across the North Sea from the southwest to the northeast showing the erosion caused by the Middle Jurassic uplift. 
neither seismic evidence nor well data indicate presence of the Fjerritslev Formation. In the Danish Subbasin, the formation thins towards the Ringkøbing-Fyn High and the sequences found close to the high belong to the oldest parts of the formation (Michelsen 1978b) like those in the Salt Dome Province (Jensen et al. 1986) and in the Norwegian sector (Vollset \& Doré 1984). The ages and the present day distribution of the formation suggest that it was originally more widely distributed and that substantial parts were removed by erosion before deposition of the overlying Middle Jurassic sediments (see also Gowers \& Sæbøe 1985). On the basis of comparisons between the thicknesses of the formation in the Salt Dome Province and in the Danish Subbasin, Holm (1983) has estimated that more than $500 \mathrm{~m}$ of sediment were removed.

A section across the North Sea from the southwest to the northeast (fig. 12) shows how this erosion removed progressively deeper parts of the Lower Jurassic deposits as the central North Sea is approached. A full Lower Jurassic marine sequence occurs at the southwestern end of the section, viz. the Aalburg and Werkendam Shale Formations in the Anglo-Dutch Basin. In the Dutch Central Trough, the marine sequence is

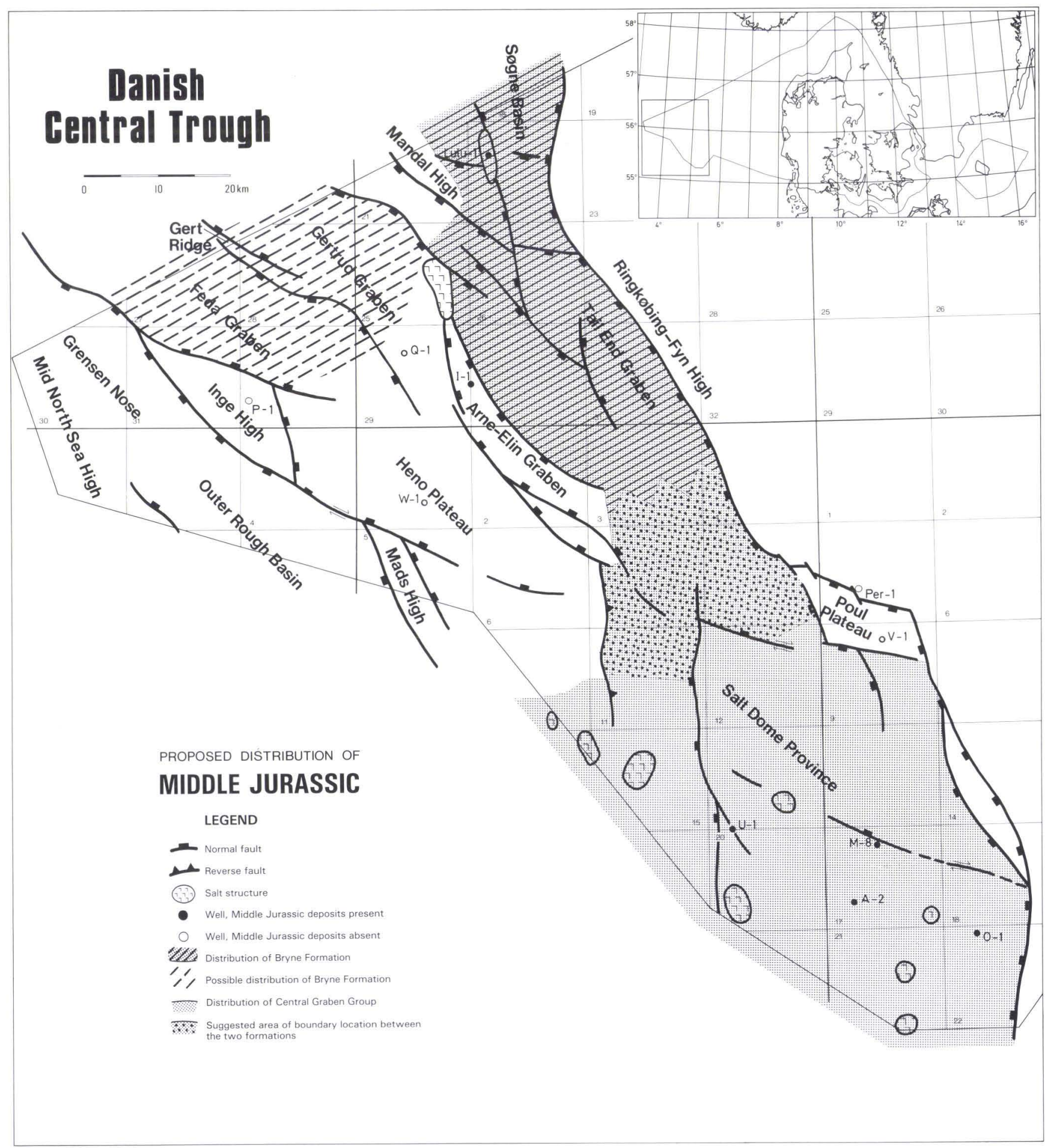

Fig. 13: Assumed extent of Middle Jurassic sediments. 
truncated by an unconformity at top Aalenian beds. In the southern part of the Danish Central Trough, the Fjerritslev Formation is truncated so that Upper Sinemurian beds are the youngest remaining. The formation is absent further north in the Central Trough. As appears from the previous paragraphs, a corresponding cut-off of the Fjerritslev Formation is seen on an approach towards the central North Sea from the northeast. The erosion probably followed the central North Sea uplift described by Eynon (1981). According to him, the uplift began in late Toarcian times but uplift and subsequent erosion in the region covered by the correlation diagram at fig. 12 must have continued until after the Aalenian since Aalenian sediments in the Dutch Central Trough are the youngest pre-erosion deposits in the area affected by the erosion.

\section{Middle Jurassic}

The mid Cimmerian unconformity separating Lower Jurassic and Middle Jurassic sediments was caused by the erosion described above. This erosion took place at the Middle Jurassic times, probably during the Bajocian, and was followed by deposition of sandy sediments in the Central Trough. Two lithostratigraphic units are recognized in the Danish sector (Jensen et al. 1986): The Central Graben Group penetrated by four wells in the Salt Dome Province (A-2, M-8, O-1 and $\mathrm{U}-1$ ), and the Bryne Formation known from one well (Lulu-1) in the Søgne Basin (fig. 13).

The Central Graben Group is defined in the Dutch part of the Central Trough where it comprises three formations (NAM \& RGD 1980). Two of these occur in the Danish part: The Lower Graben Sand Formation and the overlying Middle Graben Shale Formation.

The Lower Graben Sand Formation is made up of fairly thick sandstone units interbedded with claystones and siltstones. Thin coal beds are intercalated towards the east. The formation is mainly of Callovian but also of Bajocian-Bathonian age (Hoelstad 1986a and b, Poulsen 1987).

The Middle Graben Shale Formation is dominated by clay and has intercalations of siltstone and a few sandstones. Fairly thick coal beds occur close to the base of the formation. The age of the formation is Callovian (Hoelstad 1986b, Poulsen 1987).

Two interpretations of the depositional environment of the Central Graben Group in the Salt Dome Province have been presented (Koch 1983, Frandsen et al. 1985). Both papers suggest deposition in predominantly fluvial environments with only minor marine influence. However, Hoelstad (1986a and b), after having studied the palynofacies of the group, interprets the environment as more marine than previously assumed. The Lower Graben Sand Formation of the U-1 well is accordingly interpreted as having been deposited in a marginal marine environment with strong fluvial influence. The overlying Middle Graben Shale Formation shows a higher degree of marine influence than the Lower Graben Sand Formation (N. Poulsen, pers. comm. 1986). The Lola Formation that conformably overlies the Middle Graben Shale Formation was deposited under marine conditions. The Central Graben Group and the Lola Formation in the U-1 well thus reflect a transgressive development. Similar conclusions can be drawn from the A-2 and M-8 wells.

In the U-1 well, the Central Graben Group ranges in age from the earliest to the latest Callovian and in M-8 the range is from the Bathonian to the Callovian (Hoelstad 1986a and b, Poulsen 1987). The transgression thus continued through the Callovian.

In the O-1 well, the group is represented by the Lower Graben Sand Formation, which in this well is of Bajocian-Bathonian age. Koch (1983) and Frandsen et al. (1985) present different interpretations of this sequence. Both papers assume fluvial dominance during deposition of the Central Graben Group further west. Koch (1983) suggests that the O-1 sequence reflects progradation of a delta plain over an interdistributary bay, while Frandsen et al. (1985) offer an interpretation of sediments of a flood plain extending from the west interfingering with those of an alluvial fan advancing from the east. In the light of the above interpretation of the Central Graben Group, Koch's interpretation appears most likely. Callovian deposits are not reported from the $\mathrm{O}-1$ well and the Middle Graben Shale Formation has apparently been cut out by normal faulting (Jensen et al. 1986). The Callovian transgression is therefore not reflected by the sequence penetrated in the O-1 well, although it probably did take place after the delta progradation of the BajocianBathonian.

The thickness of the Lower Graben Sand Formation in the O-1 well is much greater than in the wells further west ( $237 \mathrm{~m}$ compared to $63 \mathrm{~m}$ in M-8 and U-1). This is a result of a higher subsidence rate close to the Ringkøbing-Fyn High than in the centre of the Salt Dome Province, and subsequently of an earlier start of sedimentation close to the Ringkøbing-Fyn High than further to the west, as indicated by the biostratigraphic analyses. Seismically it can be shown that the Middle Jurassic sequence thickens from the O-1 well towards the Ringkøbing-Fyn High (Møller 1986). Furthermore, it is believed that a local depocentre developed on the downfaulted, western side of the north-south trending fault west of U-1 (fig. 13), so that a Middle Jurassic sequence thicker than in U-1 may be expected here (Møller 1986).

The Bryne Formation, as defined in the Norwegian sector of the North Sea (Vollset \& Doré 1984), is a sequence of sandstones interbedded with siltstones and 
claystones and containing scattered coal beds. In the Lulu-1 well, which is located on a salt structure, the formation is $129 \mathrm{~m}$ thick, but seismic evidence indicates that greater thicknesses are to be expected both in the Søgne Basin and in the Tail End Graben. The formation is of Bathonian-Callovian, possibly Bajocian age (T. Hoelstad, pers. comm. 1985) and it is interpreted as the deposits of a deltaic interdistributary bay environment followed in the topmost part of the formation by sediments of a coastal lagoon and beach barrier environment (Frandsen 1986). These deposits are eventually overlain by marine claystones of the Lola Formation. The sequence thus represents a transgressive development similar to and more or less contemporaneous with the transgression in the Salt Dome Province.

Vail \& Todd (1981) and Hallam (1978) suggest a eustatic sea-level rise during the early parts of the Callovian and a high sea-level through the rest of the stage. The transgression assumed to have taken place in the Danish Central Trough is apparently in agreement with this interpretation.

\section{Distribution of the Middle Jurassic}

Middle Jurassic sediments are absent from major parts of the Mads, Inge and Mandal Highs and the Poul and Heno Plateaus (Møller 1986 and fig. 13). The presence of Jurassic sequences is demonstrated with varying certainty in the Outer Rough Basin, at the Grensen Nose and Gert Ridge, and in the Feda, Gertrud and ArneElin Grabens. Due to lack of adequate well information it is not possible to tell whether Middle Jurassic deposits are present.

A seismic sequence boundary termed "near base Middle Jurassic" indicates the position of the Middle Jurassic sediments in the Salt Dome Province (Møller 1986). The boundary can be followed into the Tail End Graben where it loses character because of very deep burial as a result of major Late Jurassic subsidence and sedimentation. The poor seismic resolution, together with lack of well evidence make it impossible to tell whether Middle Jurassic deposits are present all through the Tail End Graben. It is suggested that Middle Jurassic sedimentation in the Danish Central Trough took place in two separate basins, or at least that the deltaic environments of the Søgne Basin and the Salt Dome Province did not belong to the same delta. This suggestion is based on the following evidence:

1) The different Middle Jurassic sequences in the two basins.

2) Middle Jurassic coal beds in the Dutch Central Trough and the southern Danish Central Trough are characterized by very low radioactivity relative to the surrounding rocks (expressed as distinctly low, relative gamma ray radiation). This is in contrast to conditions in the northern Danish Central Trough and the Norwegian Central Trough where the radioactivity of coal beds is more or less equal to that of the rocks around them (Jensen et al. 1986).

3) Møller (1986) suggests that strike-slip faulting during the Middle and Late Jurassic moved the southern part of the Danish Central Trough westward relative to the northern part. This means that during deposition of the Central Graben Group, the Salt Dome Province may have had a more easterly position relative to the Søgne Basin than it has today.

\section{Regional development in the Middle Jurassic}

Deposition of the sandy Middle Jurassic sediments in the Central Trough started in the north where the Bryne Formation of the Norwegian sector was deposited during the Bajocian-Bathonian (Vollset \& Doré 1984). The basal part of the Bryne Formation in the Danish sector is possibly of Bajocian age but the main part was deposited during the Bathonian-Callovian (Hoelstad 1986b). Parts of the Central Graben Group of the Danish sector, close to the Ringkøbing-Fyn High, have a Bajocian-Bathonian age but the bulk of the sediments was deposited during the Callovian (Hoelstad 1986a and b, Poulsen 1987). Finally, in the Dutch sector, the Central Graben Group is of Callovian-Oxfordian age (NAM \& RGD 1980).

This gradual southward advance of sandy sedimentation is in agreement with the idea of central North Sea doming during the Middle Jurassic (Eynon 1981).

The collapse of the dome, combined with global sea-level rise, caused the Callovian transgression mentioned earlier: The Bryne Formation was deposited in fluvial to deltaic environments covering most of the southern Norwegian North Sea (Vollset \& Doré 1984). Beginning in the Callovian, marine clays of the Haugesund Formation were deposited above the Bryne Formation in the Norwegian Central Trough, a hiatus marking the boundary between the two formations. This transgressive development is similar to that seen in the Danish Central Trough except that the Lola Formation, that is the age-equivalent of the Haugesund Formation, rests conformably on the Middle Jurassic formations. The hiatus between the Bryne and Haugesund Formations may be a result of erosion during the transgression. No such erosion apparently took place in the Danish Central Trough. Although the precise relationship between the Haugesund and Lola Formations is unknown (Jensen et al. 1986), it may be assumed that they represent a depositional continuum. The transgression therefore probably advanced from the north, the erosive capability of the advancing sea front being reduced the further south it reached. In the Dutch 
Central Graben, the Kimmeridge Clay Formation rests conformably on the Central Graben Group (NAM \& RGD 1980). The lower part of the formation is of Late Oxfordian age and is assumed to be equivalent to the Lola Formation (Jensen et al. 1986). It therefore appears that the Callovian transgression from the north through the Central Trough continued into the Oxfordian reaching as far south as the Dutch sector. This is in accordance with Vail \& Todd (1981) and Hallam (1984) who believe that a new global sea-level rise took place in the Oxfordian.

\section{Late Jurassic}

The transgressive development of the Callovian and Oxfordian was followed by a period during the Kimmeridgian when the sea-level was relatively high (Hallam 1978, Rawson \& Riley 1982). In the Danish Central Trough this resulted in a change from Middle Jurassic sediments with a strong terrestrial influence to the fully marine clays of the Upper Jurassic Farsund Formation. This transition from terrestrial to marine dominance is evidenced by clays of the Lola Formation which were deposited in a low energy marine environment. Their content of vitrinitic and inertinitic organic matter suggests a fairly short distance to the coast during deposition (Jensen et al. 1986). Deposition of these clays started in the Callovian and continued through the Oxfordian and possibly into the Kimmeridgian (Jensen et al. 1986). In time-equivalent Haugesund Formation of the Norwegian Central Trough (Vollset \& Doré 1984), the sand and silt content increases upwards. A similar trend is not seen in the Lola Formation.

The Lola Formation makes up the major part of the sediments, corresponding to a seismic sequence believed to embrace the Middle Jurassic deposits and the Lola Formation (Møller 1986). Right-lateral movement along WNW-ESE trending faults probably started during deposition of these sediments (Gowers \& Sæbøe 1985, fig. 8) and the main subsidence took place in fault controlled basins formed along older, N-S to NW-SE trending, basement attached faults. The seismic sequence therefore has thickness maxima towards the east in the Tail End Graben and in its transition to the Salt Dome Province, adjacent to the bounding fault system, and local maxima at the downfaulted, western side of the fault west of the U-1 well (fig. 14). The seismic sequence is not identifiable west of the Tail End Graben - Salt Dome Province trend and the sediments are likely to be very thin or absent. The only well to confirm this interpretation is Q-1 at the transition from the Heno Plateau to the Gertrud Graben. The well contains $91 \mathrm{~m}$ of claystones assumed to belong to the Lola Formation. Well data further confirm that the formation was deposited in the Søgne Basin where it is more than $100 \mathrm{~m}$ thick, and in the Salt Dome Province where its thickness varies from 170 to more than $370 \mathrm{~m}$. At the Poul Plateau, $245 \mathrm{~m}$ of the formation overlie Triassic deposits in the $\mathrm{V}-1$ well, indicating that this fault block separated from the Ringk øbing-Fyn High some time between the Triassic and the Callovian-Oxfordian.

The Heno Formation is a silt- to sand-dominated formation found in two wells (Q-1 and W-1) at the Heno Plateau (fig. 5). It is of Middle Oxfordian to Kimmeridgian age (Jensen et al. 1986). On the basis of core material the formation is interpreted as consisting of shallow marine sediments deposited under low energy conditions, possibly in a protected bay (Koch 1983). Intervals of fine-grained sandstone with floating quartz granules reflect episodes of higher energy such as storm induced washovers into the bay. Deposition of these sediments are probably the result of erosion at the margins of a high area comprising the Inge and Mads Highs and areas further west. The erosion took place during the general transgression caused by the $\mathrm{Ox}$ fordian sea-level rise (Vail \& Todd 1981, Rawson \& Riley 1982).

The establishment of the Heno formation comprising the Oxfordian-Kimmeridgian sandstones of the Q-1 and $\mathrm{W}-1$ wells is somewhat speculative and based on lithologic similarities and age-equivalence. Owing to the presence of several small faults it has not been possible to trace the formation seismically between the two wells. A seismic reflector, believed to represent the presence of the Heno Formation, can be traced from the Q-1 well northwards into the Gertrud Graben, thus indicating that the formation may be present here. Together with Oxfordian sandstones in the B-1 well (German sector) southwest of the Mads High, the Heno Formation shows that sands were deposited along the highs of the Danish Central Trough during the Oxfordian transgression and the period of high sea-level in the Kimmeridgian. However, the presence of sands in between the clay-dominated Lola and Farsund Formations in the Q-1 well may be ascribed to a brief episode of sea-level fall (cf. Hallam 1978) or local tectonic phenomena at the Oxfordian-Kimmeridgian transition (cf. Rawson \& Riley 1982). By analogy, it may be assumed that similar sands were deposited at the flanks of other structural highs, such as the Mandal High.

Deposition of marine clays continued in the Kimmeridgian and through the Volgian into the Ryazanian. The claystones make up the Farsund Formation. A change in the organic matter from the vitrinites and inertinites of the Lola Formation to liptinite, mainly alginite, in the Farsund Formation (Lindgreen et al. 1982) indicates a tendency to more open marine conditions during deposition of this formation. Poulsen 
(1986) also reports a change from exinitic organic facies in the Lola Formation, via micrinitic facies in the lower part of the Farsund Formation, to xenomorphic facies in the upper part.

This change of conditions within the marine realm corresponds roughly to the Oxfordian-Kimmeridgian transition and may be considered as a response to a rise of sea-level at the transition. Vail \& Todd (1981) report a eustatic sea-level rise at that time and Hallam (1978) considers the Late Oxfordian-Early Kimmeridgian as a period of high sea-level after the Oxfordian transgression. A brief episode of sea-level fall at the transition from the Oxfordian to the Kimmeridgian interrupted this overall trend, followed by a rise so that the high stand was reestablished (Hallam 1978). No changes in the tectonic framework of the Danish Central Trough apparently took place at the transition, apart from increased subsidence during the Kimmeridgian in the major lows (Møller 1986). Therefore, the above-mentioned interpretations regarding sea-level changes lead to the conclusion that a gradual, minor rise of sea-level was the main cause of the change from the Lola to the Farsund Formation (see also Poulsen 1986).

The well log patterns of the Farsund Formation are

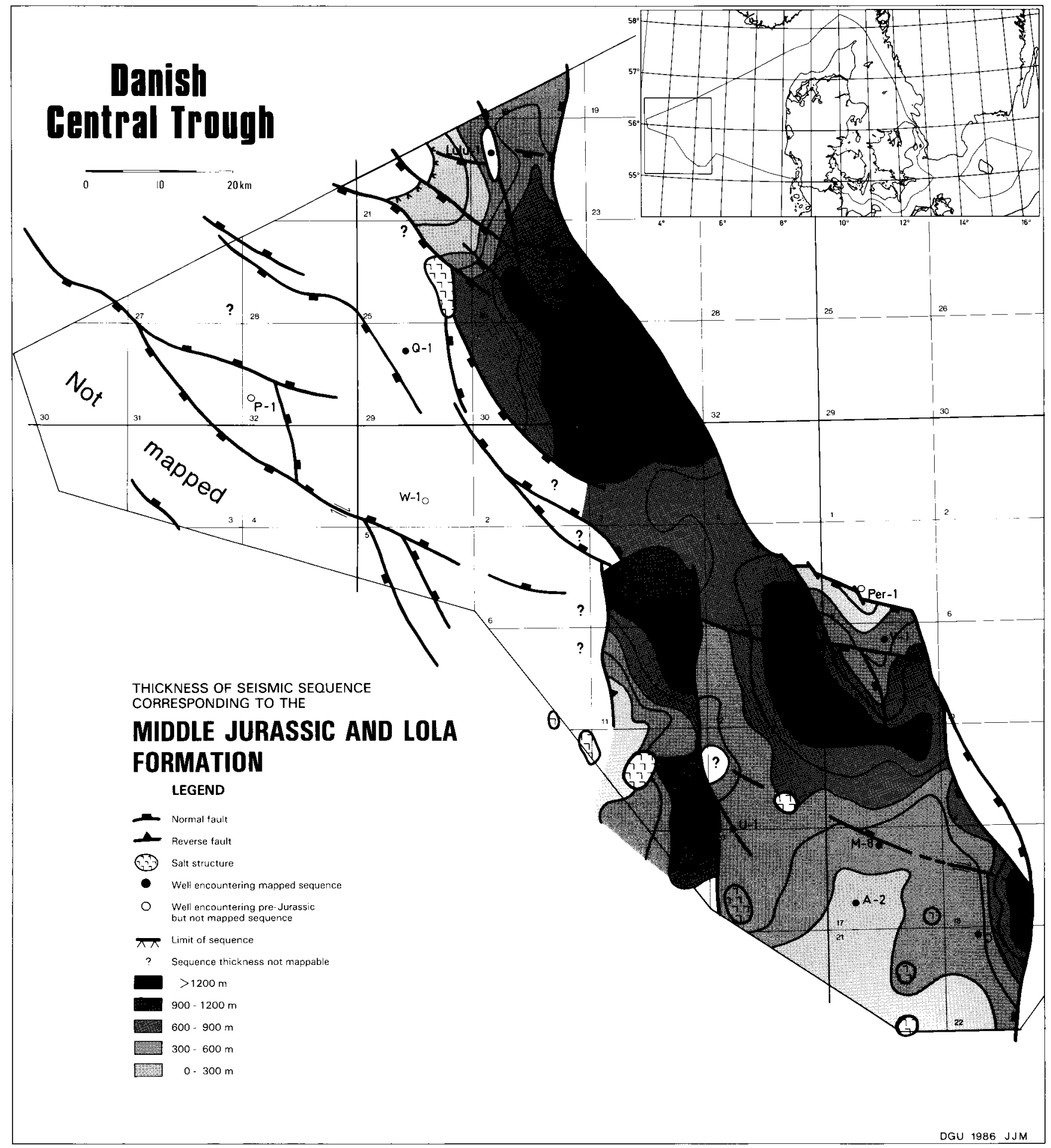

Fig. 14: Isopach map of the Middle Jurassic sequence and the Upper Jurassic Lola Formation in the Danish Central Trough. 
generally characterized by many sharp peaks of low gamma ray readings and high sonic velocities (fig. 15). The peaks reflect the presence of carbonate, most commonly developed as limestone or dolostone bands. A similar pattern is observed in the Farsund Formation in Norwegian wells (Vollset \& Doré 1984) and in the time-equivalent part of the Kimmeridge Clay Formation in the Dutch Central Trough (NAM \& RGD 1980).

Claystones of the Kimmeridge Clay from the type locality in England, contain Early Volgian limestone bands with a very high proportion of coccoliths and closely associated with oil shales (Gallois 1976). His interpretation is that the oil shales and limestones were deposited on a continental shelf where anaerobic bottom conditions necessary for the preservation of the organic matter of the oil shales were provided temporarily by coccolith blooms deoxygenating and poisoning the water before the coccoliths themselves settled as a sediment.

This interpretation of the blooms as the cause of the formation of oil shales is disputed by Tyson et al. (1979). On the basis of comparisons with present day conditions in the Mediterranean, they contend that the blooms were the result and not the cause of anaerobic bottom conditions. They envisage a cyclic development beginning with deposition of "normal" clays under oxygenated bottom conditions. A gradually increasing $\mathrm{H}_{2} \mathrm{~S}$ concentration in the lower part of the water column caused the ascent of an anaerobic, $\mathrm{H}_{2} \mathrm{~S}$ rich zone and concomitant deposition of gradually more organic carbon rich claystones. The $\mathrm{H}_{2} \mathrm{~S}$ zone eventually reached and mixed with the surface waters, supplying the nutrients for algal blooms. Deposition of the coccolith rich bands is therefore assumed to reflect the maximum development of anaerobic bottom waters.

As no relevant core material is available from the Farsund Formation of the Danish Central Trough, the exact lithologies of the carbonate bands are not known. However, it has been shown that the formation is characterized by alginitic organic material and that it is a good source rock for oil (Lindgreen et al. 1982, Damtoft et al. 1987, Østfeldt 1987). There is thus an indication of a relationship between algal dominance, oil source rocks and carbonate bands, comparable to that observed in the Kimmeridge Clay. The interpretations presented above by Tyson et al. (1979) may therefore also be applicable to the Farsund Formation.

In addition to bands of primary coccolith limestone, Tyson et al. (1979) report the presence of bands of dolomitic limestone at the Kimmeridge Clay type locality. Irwin (1980) investigated one such band from the lowermost Volgian and showed that the dolomite was formed diagenetically, a dolomitized horizon rich in primary carbonate forming the nucleus for further dolomitization in the organic carbon rich clay sediment. Some of the carbonate bands of the Farsund Formation may be such dolomitic bands and can possibly be interpreted similarly.

Some of the gamma ray and sonic peaks characteristic for the formation are caused by siltstone or sandstone beds, which are partly carbonate cemented. These thin beds occur centrally in the basin of the Salt Dome Province (e.g. the G-1 well). For interpretation, they may be viewed in context with relatively coarsegrained, clastic deposits known to be present at the basin margin (the Poul Formation, Jensen et al. 1986). The Poul Formation sediments may represent proximal density current deposits and the thin beds found centrally in the basin may be corresponding, very distal deposits. Lensoid features between seismic reflectors believed to represent lowermost Middle Volgian sediments have been observed east of the Bo-1 well. These features can be interpreted as cross-sections in lobes of density current deposits and may thus support the interpretation of the depositional processes of the Poul Formation and the thin sands. An equivalent to the thin sands may be the sandy Eldfisk Formation, which was deposited axially in the Norwegian Feda Graben during the Kimmeridgian and is assumed to be of turbidite origin (Vollset \& Doré 1984).

Thicknesses of the Farsund Formation in the Salt Dome Province range between 200 and $500 \mathrm{~m}$ whereas thicknesses of more than $1100 \mathrm{~m}$ are recorded in the area transitional between this province and the Tail End Graben (fig. 16). No well data are available from the Tail End Graben but the seismic sequence believed to represent the Farsund Formation attains thicknesses corresponding to more than $3000 \mathrm{~m}$ (Møller 1986). These substantial thickness differences may be attributed to differential subsidence during deposition. According to this interpretation, some parts of the basin subsided more rapidly than others, and resedimentation processes removed sediments from structurally high positions and deposited them in lower areas of more high subsidence rates. A stepwise increase in subsidence rate from the Salt Dome Province to the Tail End Graben during deposition of the Farsund Formation sediments is therefore suggested.

More detailed conclusions regarding differential subsidence can be drawn from comparison of thicknesses of the formation in the G-1 and E-1 wells (fig. 15): An Early to Middle Volgian interval of the G-1 well (representing the Pectinatus to Fittoni ammonite Zones) is close to $150 \mathrm{~m}$ thick whereas a corresponding interval in the E-1 well is more than $975 \mathrm{~m}$ thick. This demonstrates that the rates of deposition and subsidence in the area around the G-1 well were much lower than those in the E-1 area during part of the Early to Middle Volgian.

The Volgian and the Ryazanian are missing in the U-1 well. This hiatus may be related to the position of the well above a salt structure, salt movements possibly having caused non-deposition and/or erosion at the U-1 


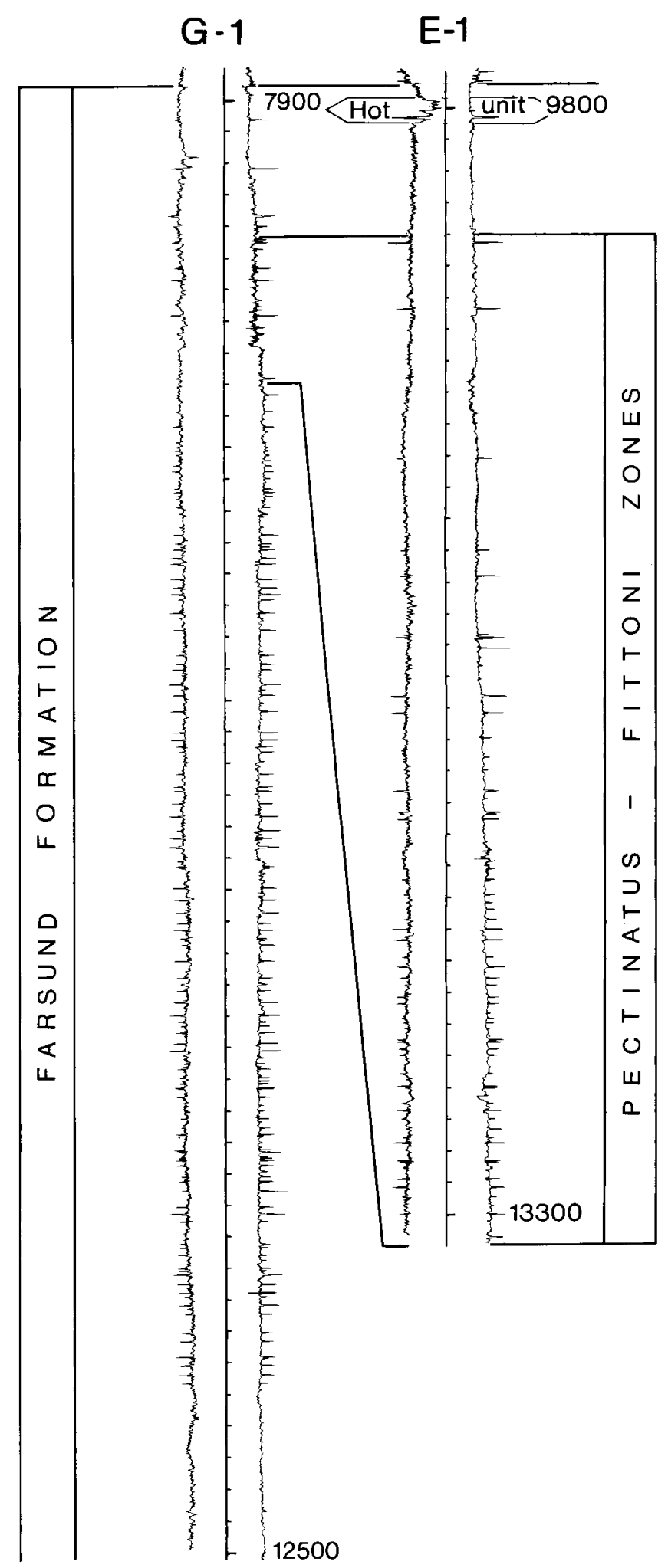

Fig. 15: Biostratigraphic correlation of parts of the Farsund Formation in the G-1 well (Salt Dome Province) and the E-1 well (Tail End Graben). For well locations see fig. 5.

site. The M-8, O-1 and Lulu-1 wells are also located above salt structures, and salt movements may similarly have been responsible for deposition of the relatively thin Farsund Formation sequences of these wells.

The claystones of the "hot unit" were deposited during the Late Volgian to Early Ryazanian. The "hot unit" is an informal lithostratigraphic unit found in the uppermost part of the Farsund Formation. It is encountered in three wells (Bo-1, E-1 and I-1, fig. 17) and its thickness varies from 25 to $68 \mathrm{~m}$ (Jensen et al. 1986). The unit is characterized by high gamma ray radiation. In the Adda- 1 and G-1 wells, the uppermost Farsund Formation also exhibits higher gamma ray readings than the underlying part, but the readings do not reach the high values of the first-mentioned wells.

The high gamma radiation of the "hot unit" is caused by a relatively high uranium content (N. Springer, pers. comm. 1984). The total content of organic carbon is as high as $5-7 \%$ (Jensen et al. 1986). The uranium content is probably related to the organic carbon content, as uranium is liable to adsorption on organic matter (Bjørlykke et al. 1975). The organic matter is liptinitic, as in the rest of the Farsund Formation (Jensen et al. 1986) and the unit also contains several distinct carbonate bands. The depositional environment of the "hot unit" apparently did not differ significantly from that of the rest of the Farsund Formation, as discussed above. Rawson \& Riley (1982) believe that the Middle Volgian to Early Ryazanian was an important period of regression in the North Sea region. Enclosed basins with restricted bottom water circulation, favouring the preservation of organic material, may have formed during this regression, leading to deposition of the clays of the "hot unit" and similar units, e.g. the Mandal Formation, known from the Norwegian sector.

The seismic sequence corresponding to the uppermost part of the Farsund Formation probably includes the "hot unit" (Møller 1986). The sequence is mainly present in the Tail End Graben and wedges out southwards into the Salt Dome Province (fig. 17). Westwards, an inverted fault zone makes seismic correlation difficult. Slightly increased gamma ray radiation in the entire Volgian sequence in the Q-1 well may, however, suggest that the development in the Gertrud Graben, and probably also the Feda Graben, during this period was fairly similar to that in the Tail End Graben. In the Lulu-1 well, located in the Søgne Basin, a similar type of sedimentation took place during the Volgian. Upper Volgian and Ryazanian strata are not present in Lulu-1.

The sediments corresponding to this seismic sequence were deposited from the Middle Volgian through the Ryazanian, i.e. after the Early to Middle Volgian period of very high subsidence rates (fig. 7). Subsidence rates were moderate to small (Poulsen 1986) and the "hot unit" appears to occur in areas where Middle Volgian to Ryazanian deposition was below its maximum. Where maximum deposition occurred (e.g. in the Adda-1 area) the "hot unit" is absent. This pattern suggests that in the areas of maximum deposition clastic sedimentation overshadowed the production of organic material so that a less "hot" but thicker sequence developed. 
In the V-1 well at the Poul Plateau a 33 m thick sequence of very fine-grained sandstones and siltstones grading into claystones is intercalated in the uppermost Farsund Formation. The sequence makes up the Poul Formation and was deposited during the Volgian (Jensen et al. 1986). No conventional core information exists from the formation, but on the basis of dipmeter log studies Hansen \& Buch (1982) conclude that it apparently makes up a series of sand sheets interbedded with claystones. With the position of the formation fairly close to the boundary fault towards the Ring-
købing-Fyn High, they further assume that it was deposited from density currents that originated from the high in connection with fault movements. Grain-sizes increase slightly upwards (Koch 1983) and may reflect progradation of the sandy sediments. Thus, combined sedimentological and seismic evidence from marginal and central parts of the Tail End Graben and Salt Dome Province suggest that coarse-grained clastic material was deposited at the foot of fault controlled slopes.

The formation probably has a restricted lateral ex-

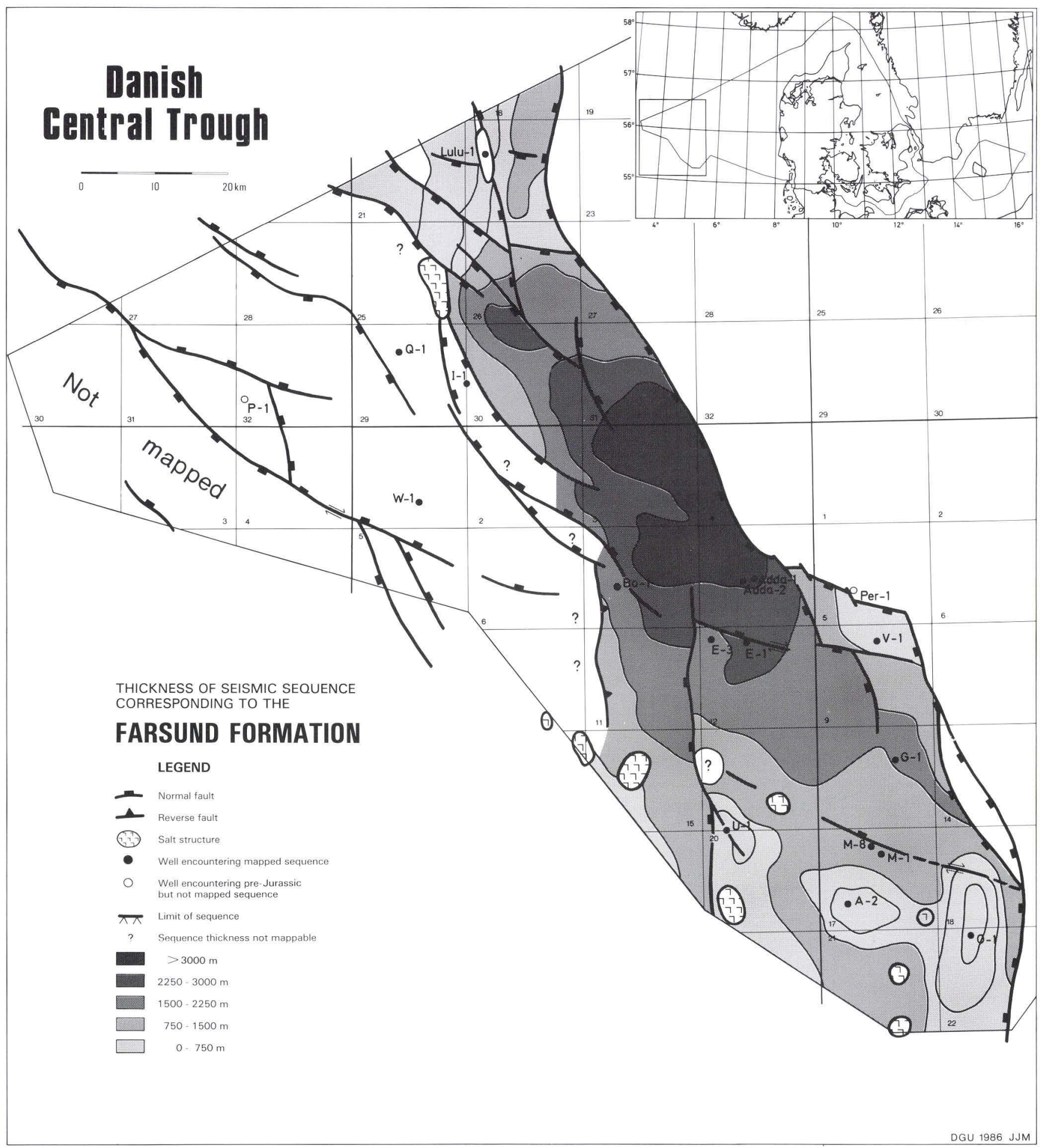

Fig. 16: Isopach map of the Upper Jurassic Farsund Formation in the Danish Central Trough. 
tent, but similar sediments may have been deposited elsewhere along the eastern margin of the Central Trough.

\section{Basin development in the Late Jurassic}

The Oxfordian was a period of major transgression in the North Sea region (Hallam 1978, Vail \& Todd 1981), and marine sedimentation dominated in the Danish Central Trough. Initiation of strike-slip movements was contemporaneous with deposition of the clays of the Callovian to Oxfordian Lola Formation in the areas of subsidence to the south and east, whereas sands of the Oxfordian to Kimmeridgian Heno Formation, and possible equivalents, were deposited along the more stable highs and plateaus to the west. The pattern of WNW to ESE striking right-lateral movements continued

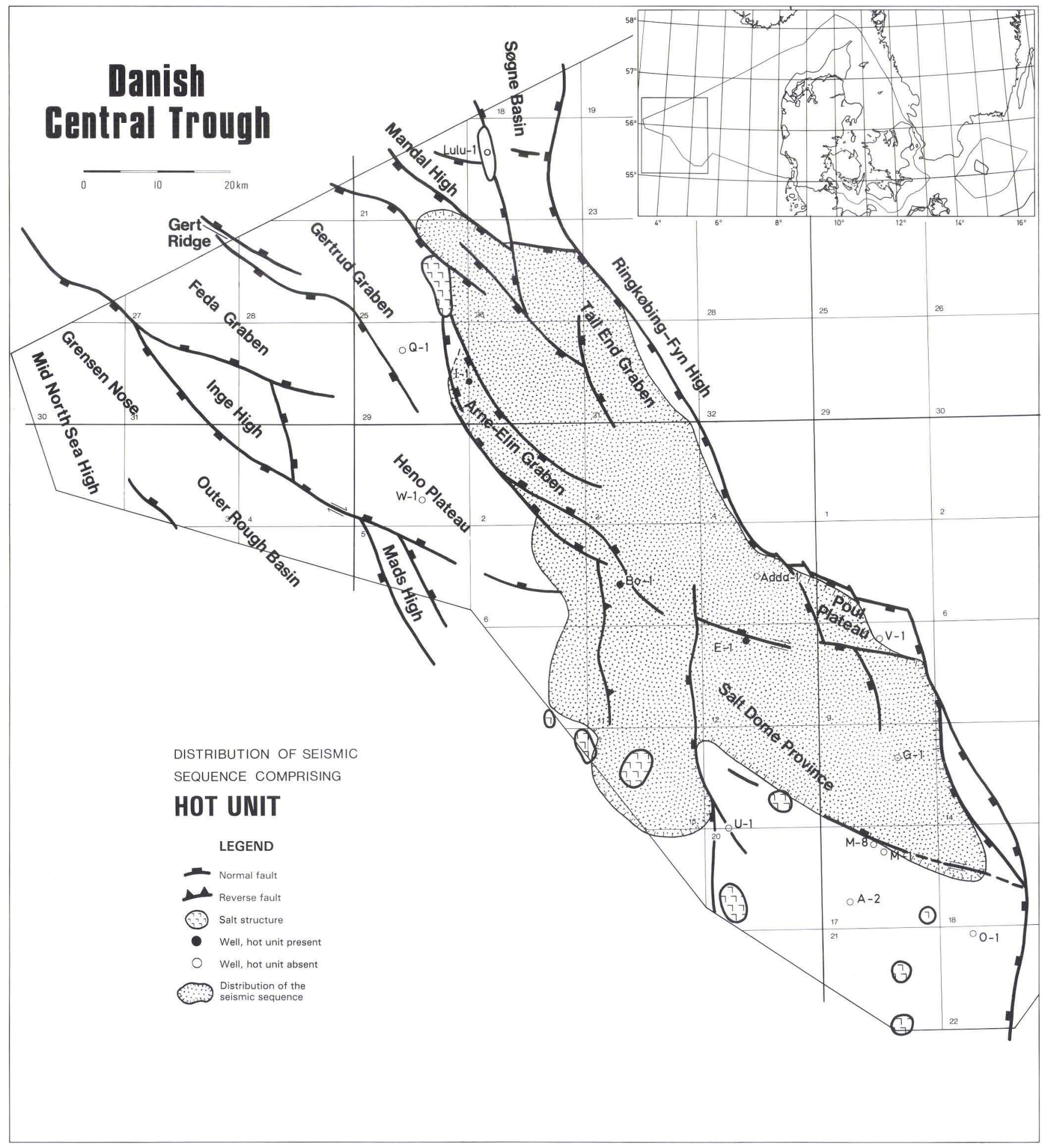

Fig. 17: Distribution of the seismic unit comprising the uppermost part of the Farsund Formation, which locally includes the "hot unit". 
throughout the Late Jurassic and the differential subsidence demonstrated in the Tail End Graben and Salt Dome Province was one result of this tectonism (fig. 7). A similar difference apparently existed between the Søgne Basin and the Tail End Graben, the former having the lowest rate of subsidence (Gowers \& Sæbøe 1985).

Subsidence continued during the Kimmeridgian and the sea-level was relatively high. The clays of the Kimmeridgian to Ryazanian Farsund Formation were deposited over most of the Central Trough, and continued strike-slip movements caused continued differential subsidence in the Tail End Graben and Salt Dome Province.

During deposition of the Farsund Formation, activity of the fault west of the U-1 well gradually ceased and the largest thicknesses of sediment were deposited in the central part of the Tail End Graben, north of a major strike-slip fault (Møller 1986). Movement along this fault further led to the formation of the Arne-Elin Graben as an additional basin. According to Møller (1986), this graben opened in late Late Jurassic.

As a response to fault activity, density currents may have been generated along the slopes of the Ringkøbing-Fyn High and deposited sediments such as the sandy Poul Formation as intercalations in the dominantly clayey sequence.

The Feda and Gertrud Grabens were important areas of subsidence during parts of the Jurassic. A seismic sequence corresponding to at least $2200 \mathrm{~m}$ of sediments is recognized in the Danish part of both grabens, and it is assumed that the base of the sequence is close to the base of the Middle Jurassic (Møller 1986). Lack of well information makes it difficult to identify the formations present in the grabens. At least the Feda Graben developed in a similar fashion to the Tail End Graben, and Middle Jurassic sediments are probably present (Gowers \& Sæbøe 1985). Data presented by Vollset \& Doré (1984) suggest that the Upper Jurassic Farsund and Lola Formations (or the Haugesund Formation, equivalent to the Lola Formation) are present. More coarsegrained sediments of turbiditic origin, like the Kimmeridgian Eldfisk Formation (see Vollset \& Doré 1984), may also occur.

Further southwest, the Outer Rough Basin became separated from the Mid North Sea High and subsided relative to both this high and to the Inge and Mads Highs. No well information is available from the Danish part of this basin. However, Gowers \& Sæbøe (1985) assume that up to $600 \mathrm{~m}$ of sediments accumulated here during the Late Jurassic, and Oxfordian sandstones are seen in the B-1 well which is situated in the German part of the basin.

The Heno Plateau occupies an intermediate position in the Middle and Late Jurassic development. It has less than $1000 \mathrm{~m}$ of Jurassic sediments (Møller 1986) and, provided that the W-1 and Q-1 wells are repre- sentative for the plateau, it appears that these sediments are all of Late Jurassic age. Their thickness is modest in comparison with the large thicknesses of Late Jurassic deposits in the rapidly subsiding basins.

High subsidence rate ceased at some time during the Middle Volgian and a period of much lower subsidence rate ensued. Simultaneously there was a eustatic fall in sea-level (Rawson \& Riley 1982, Poulsen 1986). During the following period of low sea-level, the highly radioactive "hot unit" developed as part of the Farsund Formation. It was possibly deposited in small, enclosed basins during the Late Volgian and Early Ryazanian (Rawson \& Riley 1982).

\section{Early Cretaceous}

Deposition of the organic carbon rich sediments of the Farsund Formation continued across the Jurassic-Cretaceous boundary until mid or late Ryazanian times (Rawson \& Riley 1982, Birkelund et al. 1983, Heilmann-Clausen 1987, Poulsen 1987).

The boundary between the Ryazanian to Hauterivian Valhall Formation and older sediments was previously regarded as being an unconformity of regional significance, frequently named the late Cimmerian unconformity or base Cretaceous unconformity. Rawson \& Riley (1982) disputed and rejected the concept of a basin-wide unconformity. Instead they believe that the boundary represents a facies change and suggest that this change was caused by a Late Ryazanian transgression which brought about changing water circulation patterns in the various North Sea basins, thereby terminating deposition of organic carbon rich clays.

Lithologically the boundary between the Farsund and Valhall Formations is characterized by a change from dark, organic carbon rich claystones to light grey, calcareous claystones. The change in lithology coincides with a change in content and type of organic matter. The Farsund Formation, including the "hot unit", has a total average organic carbon content of 3-5\% (Lindgreen et al. 1982, Damtoft et al. 1987) with a high average content of liptinite, mainly bituminite (amorphogen, Hoelstad 1986b). The overlying Valhall Formation has a much lower total organic carbon content of $0.3-0.6 \%$ and a very low amorphogen content. The organic matter is also characterized by a relatively higher content of both liptinite (phyrogen) and land derived organic material.

The boundary between the Farsund and Valhall Formations in the Danish Central Trough has recently been investigated biostratigraphically (Birkelund et al. 1983, Heilmann-Clausen 1987, Poulsen 1987). The results of these studies, combined with those of Rawson \& Riley (1982), clearly indicate that the contact between the Farsund and Valhall Formations in most 
cases is conformable in the basinal areas. Unconformities are present on certain structural highs but these highs existed before the end of the Jurassic, and some remained as highs into the Early Cretaceous. Such unconformities can hardly be related to the sea-level fall at the end of the Jurassic. This is supported by seismic data which rarely exhibit truncated reflection patterns at the boundary but show concordance or toplap relations (Vejbæk 1986). Following Rawson \& Ri- ley (1982) we agree that the boundary appears to be an isochronous surface, although biostratigraphical data from the Danish sector (Heilmann-Clausen 1987) are less conclusive than those of Rawson \& Riley (1982).

The extensional tectonic regime of the Late Jurassic continued in the Early Cretaceous, but with much lower subsidence rates (fig. 7) and with maximum thicknesses of the total Lower Cretaceous less than

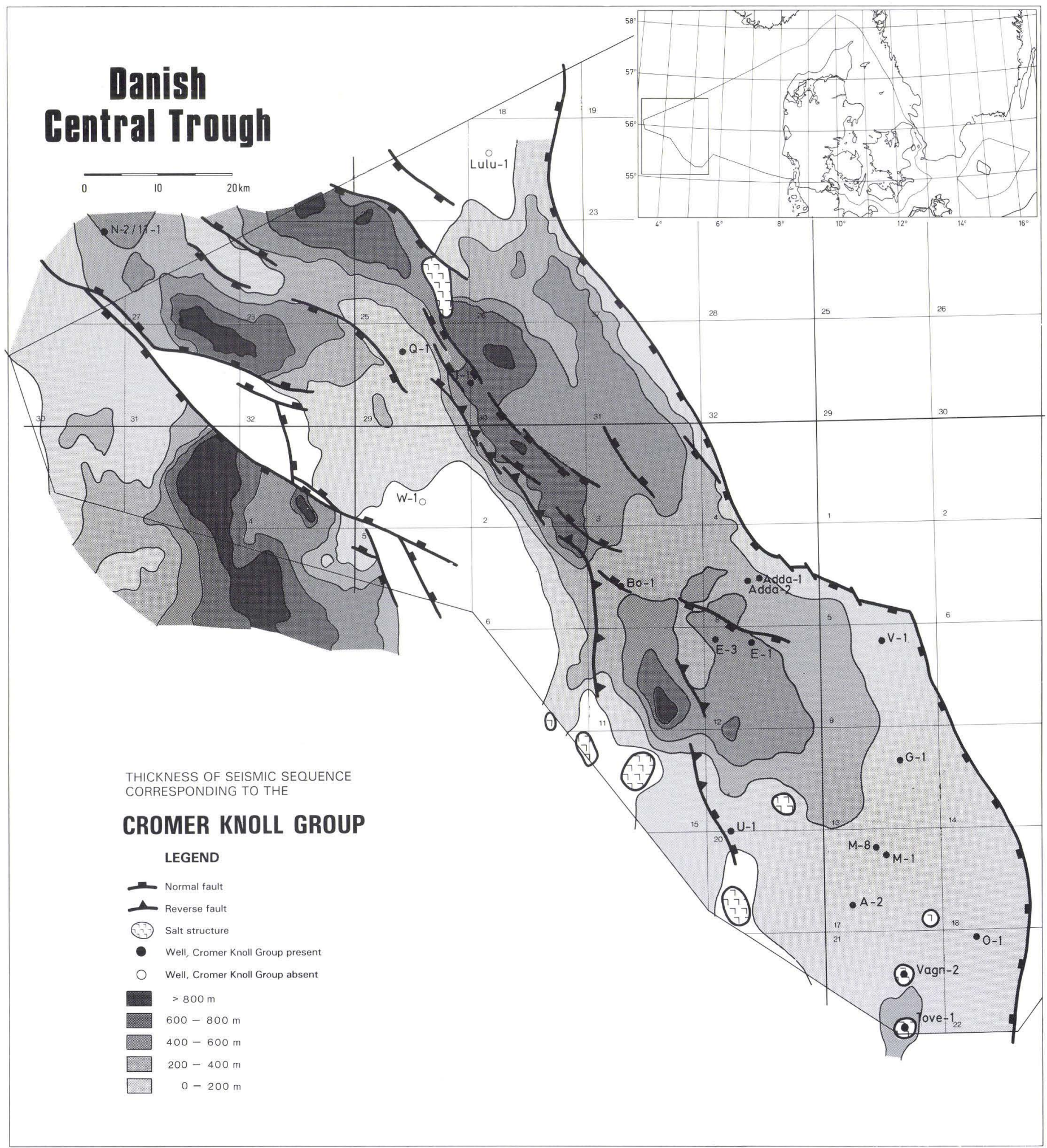

Fig. 18: Isopach map of the Lower Cretaceous Cromer Knoll Group in the Danish Central Trough. 
$1000 \mathrm{~m}$ (fig. 18). Subsidence occurred mostly in the same basins which were active during the Late Jurassic. An exception is the Søgne Basin which was probably elevated during latest Jurassic time and subsequently underwent erosion during the Early Cretaceous. Furthermore, the Outer Rough Basin and Grensen Nose, which had hitherto shown limited subsidence, became more active. The WNW-ESE striking, right-lateral strike-slip faulting apparently ceased, whereas the conjugated NNW-SSE striking, left-lateral fault system continued to be active, as can be seen along the ArneElin Graben fault system (fig. 6).

Following the Late Ryazanian transgression, the Leek Member, the basal part of the Valhall Formation, was deposited in Late Ryazanian to earliest Valanginian time (Jensen et al. 1986, Heilmann-Clausen 1987). The member has a significantly higher content of carbonate than the underlying Farsund Formation and the remaining part of the Valhall Formation above (fig. 19). The member consists of grey, calcareous claystone interbedded with marl- and limestone and occasional siltor sandstone layers. Contrary to what is observed in the Farsund Formation, the carbonate consists of calcite (Thomsen et al. 1983) and it is assumed to have originated from calcareous nannoplankton skeletons that briefly became an important constituent of the sediment.

It is tentatively suggested that clastic sedimentation rates were reduced in the basinal areas because the clastic supply was trapped in land-near waters, newly deepened during the Late Ryazanian transgression. The Leek Member is assumed to be present centrally in all basins within the Danish Central Trough.

During latest Ryazanian to earliest Valanginian times deposition of more clastic-rich sediments resumed and continued until mid Hauterivian time (Heilmann-Clausen 1987). The resulting sequence constitutes the remaining part of the Valhall Formation (Jensen et al. 1986). The sediments comprise calcareous claystones with subordinate layers of marlstone or limestone and occasional silt or sand layers. At the Pollerne Ridge (Bo-1, fig. 6) the Valhall Formation is developed as a more marly facies.

The Valhall Formation was deposited during continuous relative rise of sea-level interrupted by minor periods of sea-level fall (Rawson \& Riley 1982). In the Danish Central Trough the associated transgression is evidenced by basin expansion seen as a pronounced onlapping trend of the seismic units corresponding to the Valhall Formation (see fig. 20 and Vejbæk 1986). The intervening regressive phases are poorly documented, but in the Salt Dome Province internal reflectors of the seismic LCB unit (sensu Vejbæk 1986) are truncated by the overlying seismic unit. This truncation suggests the presence of a local unconformity that may correlate chronologically with one of the two Early Valanginian unconformities reported from onshore localities by Rawson \& Riley (1982).

In the Salt Dome Province the seismic unit corresponding to the lower part of the Valhall Formation (including the Leek Member, see fig. 19), has a lobate lensoid shape and internal reflectors onlap or downlap onto the substratum and a submarine fan environment was suggested for the unit (Vejbæk 1986). The palynofacies of the corresponding sequences in the E-1 and Adda- 1 wells are characterized by extraordinarily low contents of bituminite (amorphogen) and rather high contents of terrigenous organic matter (Hoelstad 1986b). Mineralogically the unit in E-1 is characterized by higher quartz contents than elsewhere in the Valhall Formation (cf. Thomsen et al. 1983, Hoelstad 1986b, Vejbæk 1986). Reworked Triassic and Jurassic microfossils are frequently reported from this interval (Hansen \& Buch 1982) and the dipmeter logs exhibit a "high energy pattern". The combined evidence supports the concept of a fan model. The shape of the unit as mapped in the Salt Dome Province suggests that the fan system was elongate in shape. The fan body was probably provided with clastic material enriched in terrigenous organic matter from point sources along the Ringkøbing-Fyn High fault zone (south of the Pollerne Ridge, fig. 6), the clastics being transported by gravity flows in a west to southwesterly direction (see also comments below concerning the Vyl Formation).

In the Gertrud, Tail End and Arne-Elin Grabens the thickness variations of the lowermost seismic unit of the Valhall Formation are clearly controlled by rotational block-faulting. The isopach patterns are consequently elongated parallel to the controlling faults (Vejbæk 1986). In these basins the mineralogic composition and palynofacies are less influenced by terrigenous components (e.g. the I-1 well, Thomsen et al. 1983, Hoelstad 1986b). Much of the thickness variation was probably caused by remobilization of sediments during phases of differential subsidence. This mechanism probably applies in particular to the intrabasinal depocentres like those situated southerly in the ArneElin Graben and northeast of the I-1 well (fig. 6).

The depocentres in the Gertrud and Tail End Grabens probably had multiple or linear sediment sources along the emerged Mandal and Ringkøbing-Fyn Highs respectively. Gravity flows were triggered on the coastal slopes of the highs and transported sediment to the basins. A "slope-apron" depositional model (sensu Stow et al. 1984) is therefore suggested for these basins. It must be stressed, however, that suspension deposition continued as a significant process in most basins as implied by the frequent occurrence of pelagic marl or limestone beds.

The remaining part of the Valhall Formation is seismi- 


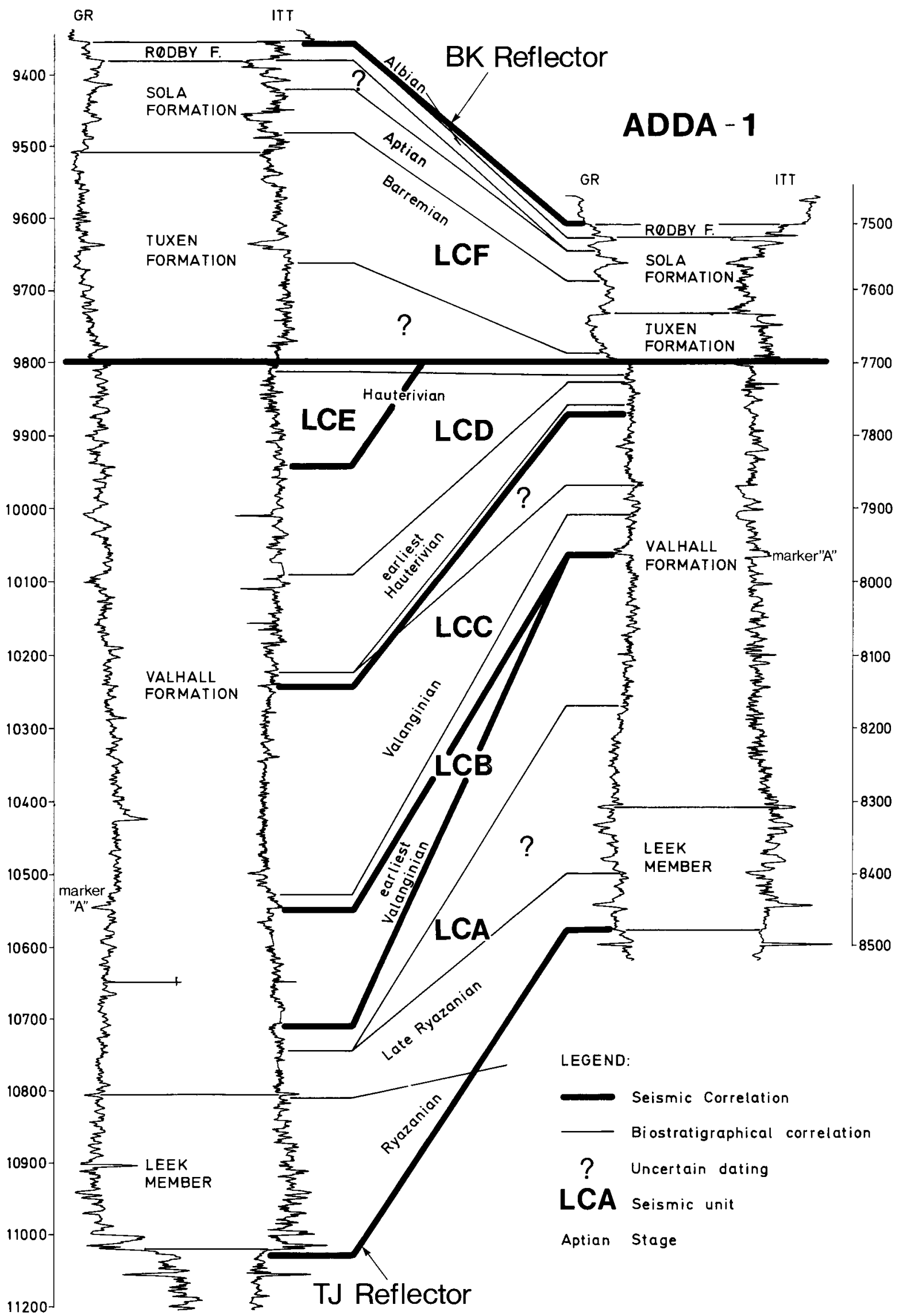

Fig. 19: Lithostratigraphy, seismic units and chronostratigraphy (based on palynology) for the Adda-1 and I-1 wells. Log marker " $A$ " is also indicated. The apparent diachronous nature of the basal Valhall reflector may be explained by reworked fossils. See fig. 6 for well locations. (Modified from Heilmann-Clausen 1987). 
cally characterized by further basin expansion, and the basin continued to exhibit a fault controlled subsidence and sedimentation pattern. However, thickness variations of the seismic units indicate that the subsidence rate varied in magnitude with time from basin to basin (cf. Vejbæk 1986)

Gravity flow deposition is believed to have continued as an important thickness controlling factor by redistribution of sediments, although its significance prob- ably decreased since the lithology becomes increasingly dominated by pelagic carbonate, and thickness variations become less pronounced upwards through the Valhall Formation. In the early Late Hauterivian a small inversion phase resulted in weak truncation on the top of the Valhall Formation, as seen for instance in the Salt Dome Province (Vejbæk 1986, Jensen et al. 1986).

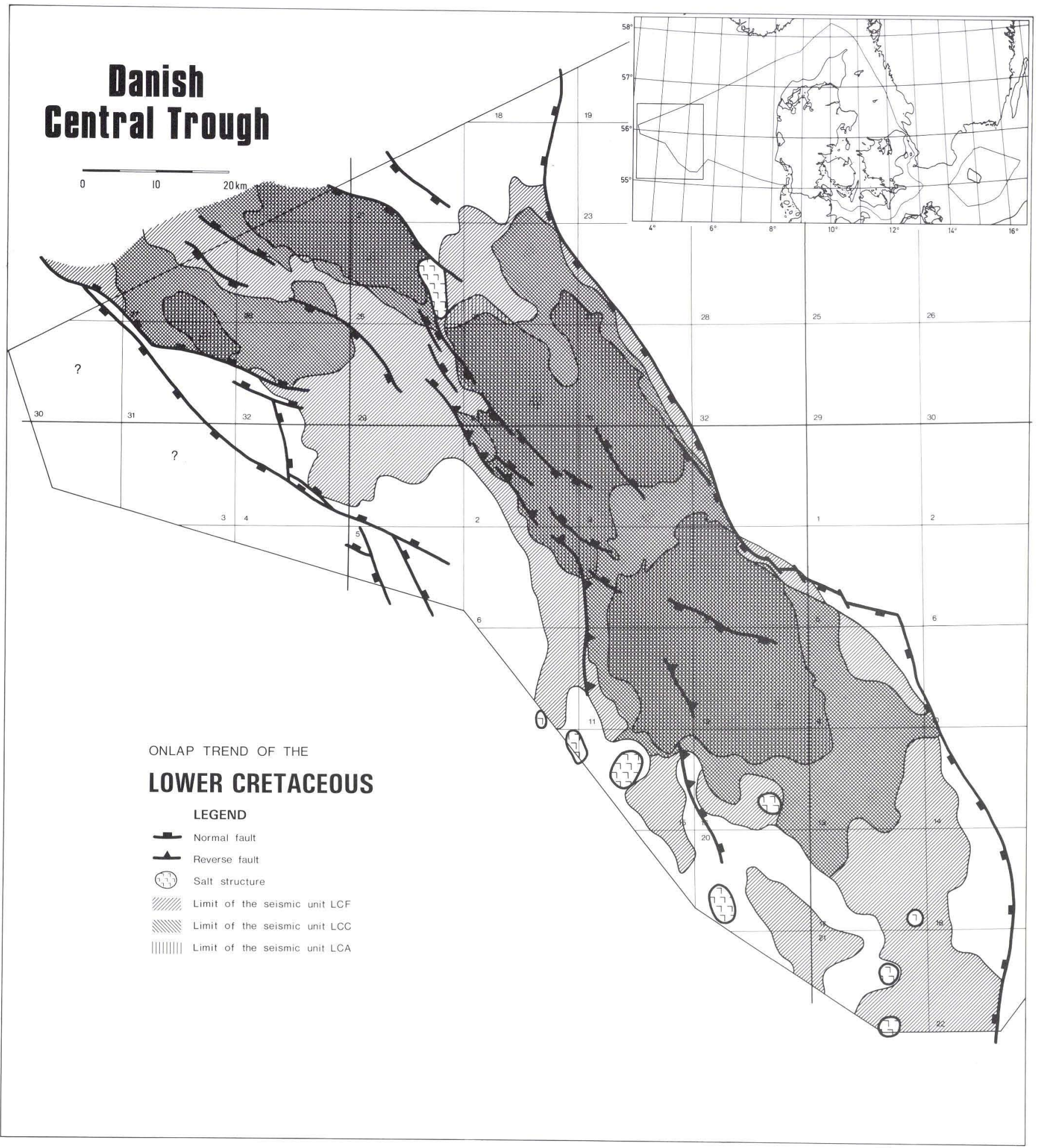

Fig. 20: Map showing extent of seismic units corresponding to the lowermost part of the Valhall Formation (unit LCA), the third seismic unit within the Valhall Formation (unit LCC) and the unit embraching the Tuxen, Sola and Rødby Formations (unit LCF). The pronounced onlapping trend of the Lower Cretaceous is evident (cf. Vejboek 1986). 
The Vyl Formation is only known from the V-1 well where it is $43 \mathrm{~m}$ thick, occurring above the Farsund Formation (Jensen et al. 1986). The sediments are mainly siltstone with subordinate layers of sandstone, silty claystone and marlstone. The organic matter is mainly of marine origin but with strong terrestrial influence (Hoelstad 1986b), a feature that distinguishes this formation from the Poul Formation which is also present in this well (see above). Recent age determinations indicate that the formation was deposited within the time-span Late Ryazanian to Early Valanginian (Heilmann-Clausen 1987).

The formation cannot be mapped seismically because of its limited thickness. Nevertheless, Vejbæk (1986) suggests a proximal position - regarding sediment source - of the Vyl Formation relative to the lowermost seismic unit of the Valhall Formation (see under the Valhall Formation). This interpretation is based on an observed increase in reflection amplitude towards the V-1 well presumed to reflect an increased

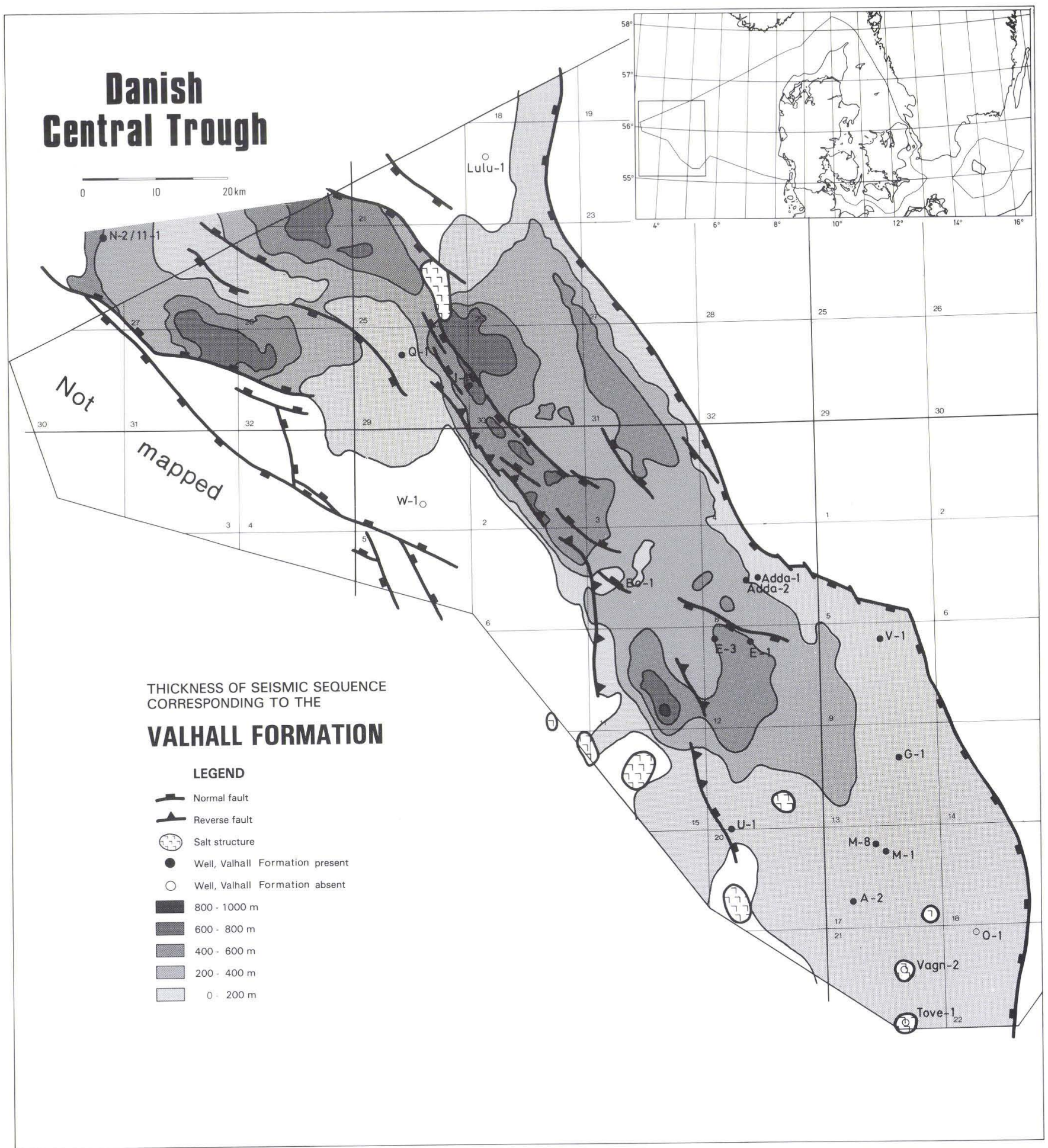

Fig. 21: Isopach map of the Lower Cretaceous Valhall Formation in the Danish Central Trough. 
content of coarse-grained siliciclastics. As stated previously, major parts of the lowermost seismic unit are believed to have been deposited as gravity flow deposits.

The absence of cores from the formation reduces the reliability of environmental interpretations. However, on the basis of dipmeter data and the location of the well close to the eastern bounding faults of the basin, Hansen \& Buch (1982) suggest a submarine fan depositional environment for the sequence, though, considering the rather fine-grained nature of the sediments, probably representing a rather distal part of a fan. Thin silt- or fine-grained sandstone beds are frequently reported from contemporaneous parts of the Valhall Formation, especially in wells close to the eastern bounding faults of the Salt Dome Province. These beds may be interpreted as distal density current deposits.

Although data are sparse and other depositional models might apply, deposition from density currents appears to be the most likely interpretation of the $\mathrm{Vyl}$ Formation.

It is believed that the Vyl Formation is developed marginally along the Ringkøbing-Fyn High. The sandy Poul and Vyl Formations in the V-1 well and separated by c. $70 \mathrm{~m}$ of the Farsund Formation may merge into one coherent sand body closer to the high. Time-equivalent sand bodies, developed as fringing sands along other structural highs, cannot be discarded.

Until mid Hauterivian time the tectonic stress system had been tension-dominated, resulting in normal faulting and differential basin subsidence. The subsidence pattern of the various Early Cretaceous basins was governed by right-lateral wrenching in a WNW-ESE direction. Of even greater importance was left-lateral transtensional wrenching along the conjugate NNWSSE direction (Gowers \& Sæbøe 1985, Vejbæk 1986). At mid Hauterivian time the tectonic system changed to one dominated by compression, resulting in weak inversion governed by right-lateral compressional wrenching along a NNW-SSE direction. The mid Hauterivian and subsequent phases of inversion are clearly reflected in both the areal extent and thickness variations of the seismic sequences mapped by Vejbæk (1986). From Late Hauterivian time differential basin subsidence abated, subsidence rates decreased, and much broader depocentres were developed. Basins which hitherto had been actively subsiding show signs of initial inversion whereas former highs started to subside (e.g. the Pollerne Ridge).

Seismically, the remaining part of the Lower Cretaceous sequence is included in the uppermost seismic unit corresponding to the Tuxen, Sola and Rødby Formations. The base of this unit is marked seismically by an unconformity, indicated by the truncation of underlying reflectors. The areal distribution of the unit indicates a further basin expansion interpreted as result- ing from a continued relative rise of sea-level (Rawson \& Riley 1982, Vejbæk 1986). The unit encroaches onto e.g. the Heno Plateau and for the first time the Gert Ridge became inundated. The unit is absent in large areas in the Salt Dome Province owing to erosion or non-deposition as a result of later or contemporaneous inversion.

The Tuxen Formation was deposited in Late Hauterivian to Middle or Late Barremian time (Jensen et al. 1986, Heilmann-Clausen 1987, Thomsen 1987). The formation consists of bedded and burrowed marlstone and chalk, with chalk becoming the dominant lithology towards the top. As seen in fig. 7 the change in facies from the claystones of the Valhall Formation to the marlstone and chalk of the Tuxen Formation is coeval with a further decrease in subsidence rates in the various basins. The Valhall-Tuxen Formation facies change was probably mainly caused by a decrease in siliciclastic sedimentation resulting from a continued relative rise of sea-level. (cf. Vejbæk 1986, Jensen et al. 1986, Jensen \& Buchardt 1987). Pelagic and hemipelagic processes are believed to have dominated deposition with hemipelagic processes decreasing in importance through the sequence as reflected by the decreasing content of siliciclastic material upwards in the formation. Occasional layers interpreted as debris flow deposits indicate the continued importance of redeposition processes (Jensen \& Buchardt 1987), however, both seismic mapping (fig. 22) and formation thicknesses as encountered in wells $(25-90 \mathrm{~m})$ reveal that thicknesses are more uniform and thickness variations much less extreme than in the Valhall Formation. The decreasing tectonic activity which characterized the Early Cretaceous from mid Hauterivian time is believed to have resulted in a decreasing importance of gravity flow processes.

The Tuxen Formation was generally deposited in well oxygenated bottom water as indicated by the low content of organic matter and intense bioturbation. However, less burrowed intervals with higher organic matter content, as well as the presence of the prominent, organic carbon rich Munk Marl Bed within the Tuxen Formation, indicate occasional periods with less oxygenated or anoxic bottom water (Jensen et al. 1986, Jensen \& Buchardt 1987). The thin (up to $1 \mathrm{~m}$ ) Munk Marl Bed, which contains up to $14 \%$ organic carbon, is widely distributed in the North Sea area and probably equivalent to the Blätterton known from the Lower Saxony Basin and Helgoland-Schleswig Basin (Kemper \& Zimmerle 1978, Jensen \& Buchardt 1987).

The Tuxen Formation is believed to be present in all basins where the uppermost seismic unit of Vejbæk (1986) is mapped and in the Outer Rough Basin and Grensen Nose. In the Salt Dome Province its distribution is probably governed by the magnitude of contem- 
poraneous and later inversion causing either non-deposition or erosion.

Chalk deposition of the Tuxen Formation came to an end in Middle or Late Barremian times. The Tuxen Formation is overlain by black, laminated, shaly marlstone rich in organic matter, alternating with sequences of burrowed marlstone with little organic matter. These sediments are included in the Sola Formation (Jensen et al. 1986) and this facies persisted until Albian (Heilmann-Clausen 1987), presumably Early Albian times. The sediments were deposited under mainly anoxic conditions, alternating with periods of more oxygenated conditions. Anoxic conditions probably culminated during the Early Aptian when marls containing up to $13 \%$ organic carbon were deposited (Jensen \& Buchardt 1987).

According to Hesjedal \& Hamar (1983) anoxic conditions were established in restricted basins formed during a regressive phase associated with the Austrian tectonic phase. They further claimed that the regressive phase gave rise to the increasing content of siliciclastics in the Sola Formation. In the Danish sector a regressive

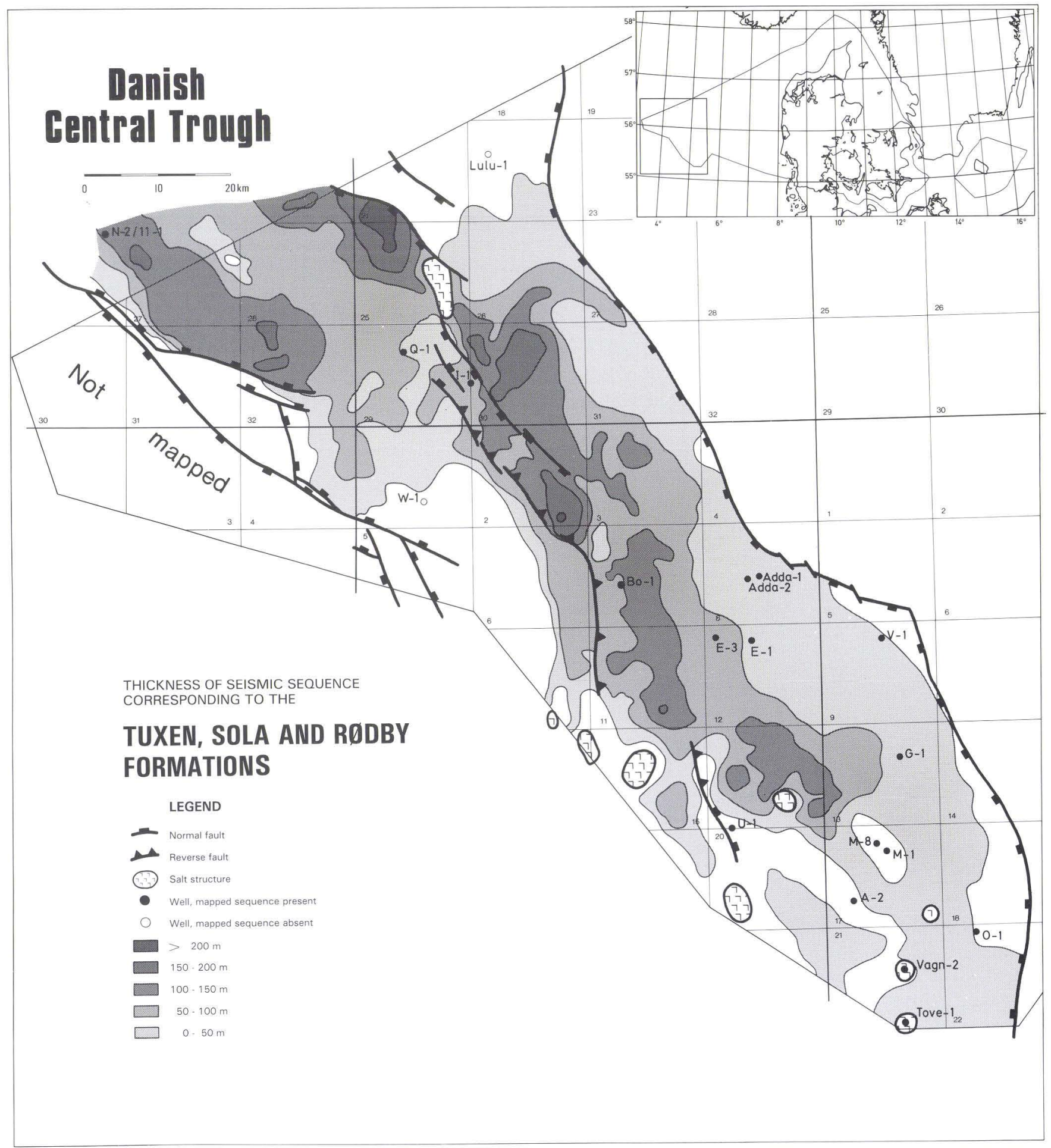

Fig. 22: Isopach map of the Lower Cretaceous Tuxen, Sola and Rødby Formations in the Danish Central Trough. 
phase coeval with deposition of the Sola Formation cannot be disclosed seismically (Vejbæk 1986). Jensen \& Buchardt (1987) suggest that the main reason for the increased content of siliciclastics is that calcareous nannoplankton generally had poor living conditions during periods of basin stagnation. However, an increased content of terrigenous organic matter in the Sola Formation compared with the Tuxen Formation indicates a subordinate contemporaneous increase in influx of terrigenous material to the basin.

The Sola Formation is widespread in both the Danish and Norwegian parts of the North Sea (Hesjedal \& Hamar 1983, Jensen et al. 1986). In released wells from the Danish Central Trough the formation attains maximum thicknesses of $38 \mathrm{~m}$. Thickness maxima are found in the Tail End Graben and Arne-Elin Graben. The thickness of the Sola Formation decreases southwards into the Salt Dome Province where the formation is only present in a few wells. Its distribution in this area is probably governed by the same factors which controlled distribution of the Tuxen Formation.

The Sola Formation is presumed to be absent on the Mads and Inge Highs and on minor parts of the Heno Plateau.

Coeval units rich in organic matter are present in the Dutch and German North Sea sectors and in the Lower Saxony Basin (NAM \& RGD 1980, Kemper \& Zimmerle 1978 and 1982). On a much larger scale, it is worth noting the time equivalence of the Sola Formation to organic carbon rich sediments encountered in the Atlantic Ocean during the Deep Sea Drilling Project (e.g. Schlanger \& Jenkyns 1976, Ryan \& Cita 1977). However, it is uncertain whether the Sola Formation is genetically associated with these deposits.

The Rødby Formation, overlying the Sola Formation, is composed of marlstones interbedded with limestones and claystones of pelagic origin. The formation is of Early to Late Albian age and locally of Early Cenomanian age. The formation becomes increasingly calcareous upwards, indicating a new transgression continuing into the Late Cretaceous and ultimately resulting in a lithofacies change to the chalks of the Chalk Group (fig. 19). Return of oxic depositional conditions is indicated by the general red coloration and low content of organic carbon (Jensen et al. 1986). The formation has a maximum thickness close to $50 \mathrm{~m}$. In the Salt Dome Province, on the Inge and Mads Highs, and probably on the Heno Plateau, it is thin or absent because it was eroded after an inversion event following the change from differential to regional subsidence with associated compression. This and subsequent inversions were the main causes for the structural outline of the base of the Upper Cretaceous.

\section{Basin development in the Early Cretaceous}

Structural development during the Early Cretaceous had many similarities to that in the Late Jurassic, i.e. continuing extensional block faulting under the influence of wrenching. The WNW-ESE orientated, rightlateral wrench system apparently decreased in importance while the conjugate, NNW-SSE directed, leftlateral wrench system continued to be active. Subsidence rates decreased drastically as tectonic activity waned (fig. 7). The decreasing tectonic activity resulted in the development of more local, laterally shifting and less pronounced depocentres.

Deposition of the organic carbon rich claystone of the Farsund Formation continued until Late Ryazanian time (Rawson \& Riley 1982, Heilmann-Clausen 1987). At this time oxygenated depositional environments became reestablished, presumably owing to a transgression which accellerated water circulation (Rawson \& Riley 1982). The boundary between the Farsund Formation and the Valhall Formation is thus believed to represent a basin-wide, isochronous facies change and not an unconformity.

After an initial period during the Late Ryazanian to presumably earliest Valanginian when deposition of the marlstones and calcareous claystones of the Leek Member occurred, deposition of calcareous claystones took over. Deposition of these claystones, included in the Valhall Formation, continued up to mid Hauterivian time. The Valhall Formation was deposited during a continuous rise in sea-level reflected by a pronounced onlapping trend. Concomitant tectonic activity caused rotational block faulting and development of major depocentres in the Outer Rough Basin, the Feda and Gertrud Grabens and in the Arne-Elin and Tail End Grabens. The shape of the depocentre in the Salt Dome Province is extensively influenced by halokinesis. In these basins the Valhall Formation attains thicknesses of up to $900 \mathrm{~m}$ (fig. 21). Thickness variations, together with seismic and sedimentological evidence, suggest, that gravity flows were important during deposition of the Valhall Formation, although their importance presumably decreased through the time-span considered. The silty and sandy Vyl Formation sediments found close to the western bounding fault of the Ringk øbing-Fyn High may have been deposited from density currents (Hansen \& Buch 1982, Jensen et al. 1986). The formation is contemporaneous with the lower part of the Valhall Formation.

At mid Hauterivian time a weak inversion, governed by a change in the tectonic stress system to a rightlateral, compressional wrench system, caused erosion of the top of the Valhall Formation. Following this event, the transgressive development continued. Deposition of siliciclastic material fell markedly as a result of 
the increasing remoteness of clastic source areas and abating tectonic activity. Marls and chalks, included in the Tuxen Formation, were therefore deposited mainly by pelagic processes up to Middle or Late Barremian time. At this time chalk deposition and oxygenated conditions of deposition terminated. Instead mainly anoxic conditions prevailed, and the Sola Formation marls rich in organic matter were deposited. In Albian times anoxic conditions were brought to an end, and deposition of the occasionally reddish and decreasingly siliciclastic marls of the Rødby Formation terminated the depositional history of the Early Cretaceous.

Together the Tuxen, Sola and Rødby Formations comprise a seismic sequence corresponding to sediments which may attain a maximum thickness of $300 \mathrm{~m}$. Decreasing importance of extensional faulting is re- flected by the much broader depocentres and minor thickness variations which characterize these basins. Major depocentres developed in the Feda and ArneElin Grabens and minor ones in the Gertrud and Tail End Grabens and in the Salt Dome Province.

The areal extent of the sequence is the greatest of all the Lower Cretaceous sequences, thus proving a continued relative rise of sea-level. Thin sediments were deposited for the first time on the Gert Ridge and on major parts of the Heno Plateau, and the unit is believed to extend into the Outer Rough Basin. In the Salt Dome Province, however, its areal extent is restricted as a consequence of contemporaneous and later inversion tectonism (Vejbæk 1986, Jensen et al. 1986). 


\section{Reservoir sediments}

The distribution and ages of potential reservoir bodies will be described in this chapter, and known reservoir formations will be characterized. Possible occurrences of further reservoir formations will be outlined on the basis of the sedimentary and structural evolution of the Central Trough.

Five siliciclastic and one carbonate reservoir formations have been described in the Jurassic and Lower Cretaceous sequences in the Danish Central Trough. They comprise the Middle Jurassic Bryne and Lower Graben Sand Formations, the Upper Jurassic Heno and Poul Formations and the Lower Cretaceous Vyl and Tuxen Formations.

Analyses of tectonic setting, provenance, depositional environment and diagenesis are important factors for evaluation of the reservoir quality. Reconstruction of the depositional environments in the sedimentary successions creates the framework for predicting reservoir quality and distribution. However, core material from the above-mentioned reservoir formations is very scarce. The Bryne Formation is represented by one cored well profile and in the Heno Formation only one core has been taken (cf. Koch 1983, Frandsen 1986, Jensen et al. 1986). Detailed analysis of the depositional environment cannot therefore be carried out on released wells from the Danish sector at the present time.

Johnson \& Stewart (1985) presented a review of the clastic reservoir rocks in the North Sea, including a classification of the Jurassic reservoir formations. The Danish reservoir formations will be treated similarly, and classified in the following four groups:

1) Fluvial, deltaic and marginal marine sands.

2) Shallow marine sands.

3) Deeper marine sands.

4) Pelagic carbonates.

\section{Fluvial, deltaic and marginal marine sands}

This group of environments is represented by the Statfjord Formation and the Brent Group (Johnson \& Stewart 1985). Regionally, these units are characterized by a parallel arrangement of major sediment bodies, with a wide lateral distribution of the facies successions.

The Middle Jurassic Bryne and Lower Graben Sand
Formations occurring in the northern and southern parts of the Danish sector respectively are believed to belong to this group of environments. Both sequences seem to represent a transgressive development. Being the best documented, the Bryne Formation is interpreted as representing development from a deltaic interdistributary bay environment to a coastal lagoon and beach barrier environment (Frandsen 1986). The approximately time-equivalent Lower Graben Sand Formation seems to represent a marginal marine environment with strong fluvial influence.

These Middle Jurassic, coarse-grained clastic formations are expected to blanket the main part of the Danish Central Trough, except from the structural highs (fig. 13). Fluvial and deltaic sediments are not expected to be found at any other stratigraphic level within the Jurassic - Lower Cretaceous sequence.

\section{Bryne Formation}

The only released well in the Danish sector penetrating the Bryne Formation is Lulu-1. The thickness of the formation here is $129 \mathrm{~m}$, with $30 \mathrm{~m}$ net sand. As this well is drilled on a salt structure, the thickness may not be representative for the formation in that area, and greater thicknesses may be expected.

The lithology of the main reservoir units is fine- to medium-grained sandstones which are occasionally coarse-grained. They are moderately to well sorted with subangular to subrounded grains. Petrographically it is a subarkosic sandstone with traces of mica. Diagenetic minerals are siderite, pyrite, ankerite, microcrystalline feldspar, quartz, kaolinite and mica (Lindgreen 1983).

The porosity is fairly high, $9-23 \%$, with an average of $20 \%$. The air permeability ranges from 0.1 to 921 $\mathrm{mD}$ with the highest values in crevasse splay and beach deposits. The main porosity reducing, diagenetic process is the precipitation of ankerite which has occasionally led to almost totally cemented sandstone beds. The main permeability reducing, diagenetic process is the growth of mica in the pore spaces (Lindgreen 1983).

The petrography of the sandstone reveals no specific evidence of the source area. The mineralogical composition and textures suggest erosion and redeposition of older sediments which may have originated from the Ringk øbing-Fyn High and the Mandal High. However, 
the model for the mid Cimmerian uplift and the subsequent erosion implies removal of large quantities of material from the study area. The sand deposited in the Central Trough may, therefore, have a complex origin, with contributions from both local and more distant sources.

The lower and marginal parts of the formation are presumed to have been deposited in a fluvial-deltaic environment. Deposits of fluvial channels, distributaries, crevasse splays and mouth bars are the main reservoir units (Frandsen 1986). The upper part of the formation is more marine influenced and beach deposits and barrier island sands are expected to have good reservoir properties here.

The Bryne Formation is expected to be present as a sheet like unit in the main part of the Tail End Graben and probably also in the Feda Graben region (fig. 13). However, the reservoir potential decreases in the deeper parts of the grabens (Damtoft et al. 1987).

\section{Lower Graben Sand Formation}

The thickness of the formation in the released Danish wells, ranges from $24 \mathrm{~m}$ to $237 \mathrm{~m}$. The net sand thickness varies from $3 \mathrm{~m}$ to $48 \mathrm{~m}$. On a regional scale, the formation tends to be thin in the western part of the trough, with increasing thicknesses towards the southeast and towards the Ringkøbing-Fyn High.

The main lithology of the reservoir unit is finegrained, moderately to well sorted sandstone, but medium- and even coarse-grained sandstone and gravel also occur. The sandstone units may be rather thick (c. $10 \mathrm{~m})$.

Petrographic analyses have not been carried out. The sandstone seems to be mineralogically mature, and it is mainly non-calcareous and contains coal pieces and pyrite. There is apparently no severe diagenetic alteration.

The average log porosities range from $19 \%$ to $21 \%$. A maximum value of $30 \%$ is found. The sand present in the Central Trough may have a complex origin, with contributions from both local and more distant sources (see the Bryne Formation above).

The Lower Graben Sand Formation is expected to be present as a sheet like unit in the southern part of the Central Trough, from the Dutch sector in the south into the southern part of the Tail End Graben (Jensen et al. 1986).

\section{Shallow marine sands}

The group of shallow marine sands is typified by the Fulmar, Piper and Ula Formations (Johnson \& Stewart 1985). Offshore and shoreface depositional environments have been suggested by Bailey et al. (1981) and
Johnson et al. (1986). These shallow marine sands show considerable lateral continuity.

The shallow marine sands are divided into two types. One type with strong tectonic influence like the Fulmar Formation, and one with only moderate tectonic influence, like the Piper and Ula Formations (Johnson \& Stewart 1985).

Among the Danish siliciclastic formations only the Heno Formation may be of shallow marine origin. It probably belongs to the latter type outlined above and is only known with certainty from the W-1 well situated on the Heno Plateau east of the Mads and Inge Highs. It is probably also present in the Q-1 well to the north. Time-equivalent sandstones occur in the B-1 well south of the highs. Seismic features indicate the presence of equivalent sands north of the Q-1 well in the Gertrud Graben.

Shallow marine sands may probably fringe the Inge and Mads Highs and the Mandal High complex, and they may even cover parts of the area between. The structural evolution of the Mandal High area created a hiatus ranging at least from the Middle Volgian to the upper Lower Cretaceous, so that erosional material may have been produced in the corresponding period in the northeastern part of the Danish Central Trough. Shallow marine sands may also be present locally along the Ringkøbing-Fyn High.

\section{Heno Formation}

In the W-1 well the thickness of this formation is $91 \mathrm{~m}$, with a net sand thickness of $67 \mathrm{~m}$. The structural position along a minor high may mean that significantly greater thicknesses are unlikely to occur.

The lithology of the main reservoir units is fine- to medium-grained, and occasionally coarse-grained, sandstone. Minor intercalations of moderately to poorly sorted sandstone with floating quartz granules occur. The sandstone is partly calcite cemented. Shell debris, glauconite and carbonized plant remains are present.

Core data from the sandstone show an orthoquartzitic sandstone, with rounded, milky granules of lithic quartzite (Koch 1983). Calcite cementation seems to be an important diagenetic process. No analysis of the diagenesis has been carried out.

The average log porosity of the Heno Formation in the $\mathrm{W}-1$ well is $11 \%$ with a maximum of $14 \%$. The core porosities and permeabilities are low because the core has been cut in the calcite cemented, fine-grained sequence. The log porosity of the sand in the Q-1 well is relatively high, around $20 \%$.

The rounded quartz granules in a poorly sorted matrix indicate that the grains are recycled and that the source area was at least partly covered by pre-Jurassic sediments. The most obvious source area is the Inge 
and Mads Highs, and possibly the Mid North Sea High. In addition to Triassic sediments, Upper Palaeozoic sediments (and volcanics?) on these highs may have contributed source material.

A shallow marine sand model implies that sandstones are expected to occur along the flanks of the Mads and Inge Highs.

\section{Deeper marine sands}

This group of siliciclastic reservoir formations is typified by the Brae and Magnus Formations (Johnson \& Stewart 1985). Compared to the shallow marine sands, distribution of this group is more restricted, and the conglomerate and sand formations often interfinger with the organic carbon rich, Upper Jurassic or Lower Cretaceous clays. These density current deposits are probably related to the extensive fault activity during the Late Jurassic. Turbiditic sands may also have been deposited in the axial parts of the basin.

The Poul and Vyl Formations, of Volgian and Ryazanian-Valanginian ages respectively, are the only reservoir formations known from the Danish Central Trough that are assumed to belong to this type of deposit. The two formations are known from the $\mathrm{V}-1$ well drilled on the Poul Plateau, close to the Ringkøbing-Fyn High. Core samples have not been taken in these formations.

Corresponding submarine density current deposits may be locally present along the Ringkøbing-Fyn High. The mineralogy and texture will depend on the composition of the pre-Jurassic rocks on the Ringkøbing-Fyn High, as discussed below. Similar deposits may also be present in connection with the Heno Formation, along the eastern bounding fault zone of the Heno Plateau.

To the north, in the Norwegian sector, the Eldfisk Formation, from the axial part of the Feda Graben, is presumed to be of turbiditic origin (Vollset \& Doré 1984). Seismic features which may indicate the occurrence of similar deposits in the deeper parts of the Danish Central Trough have been mentioned earlier in the present paper. Turbiditic sands may therefore be present in the Danish part of the Feda Graben and in the Tail End Graben. Such coarse-grained clastic sediments may have originated from the Mid North Sea High, the Inge and Mads Highs and the Mandal High. Redeposition from the Heno Plateau and corresponding areas is also possible, and it may have taken place during the Kimmeridgian-Volgian, when the rate of subsidence was greatest (see fig. 7).

\section{Poul Formation}

The only released well which has penetrated this formation is the V-1 well, situated some $5 \mathrm{~km}$ west of the main boundary fault of the Ringkøbing-Fyn High. The thickness here is $33 \mathrm{~m}$, and the net sand thickness is 11 $\mathrm{m}$. The thickness is assumed to increase towards the high.

The lithology of the reservoir unit is very finegrained sandstone and coarse-grained, clayey siltstone, poorly to moderately sorted. The grains are generally subangular. Part of the formation is calcite-cemented. The sand may become coarser-grained towards the high.

The sandstone is subarkosic. The quartz is clean and monocrystalline with parallel to weakly undulatory extinction. The feldspars are albite and orthoclase, sometimes developed as perthite. Other minerals are calcite, clays, pyrite, and glauconite. Microlignite is present. Some of the calcite is developed as spar and is thus diagenetic in origin. No proper analysis of diagenesis has been carried out.

The $\log$ porosity of $29 \%$ seems high compared to visual estimates from sidewall cores. The clay content of the sandstones reduces the reservoir quality, regardless of whether the clay has a primary or secondary origin.

The Ringkøbing-Fyn High is presumed to have acted as a source area for the Poul Formation. The mineralogically immature nature of the sandstone may indicate that a crystalline basement acted as a source. The composition of the Ringkøbing-Fyn High is very poorly known. The basement, drilled in the Per-1 well on the high (fig. 5), has been described as a microgranite by Ziegler (1982). Investigations carried out by the Danish Geological Survey point to a source consisting of a brecciated and altered (metamorphosed) layered gabbroic intrusion. If this is correct, the data from Per-1 will only provide little information about the entire high area. The presence of a Triassic sequence below the Upper Jurassic on the Poul Plateau may indicate that Triassic sediments are, or have been, present on the high itself. Seismic data indicate the presence of a sedimentary cover over parts of the high.

The best reservoir facies in the density current deposits will be sand deposited in channels. The immaturity of the sandstone reduces the reservoir potential. Improved reservoir quality could be expected where coarse-grained sediments overlie the basement on the high.

\section{Vyl Formation}

The only released well which has penetrated the $\mathrm{Vyl}$ Formation is V-1 where it is $43 \mathrm{~m}$ thick with a net sand thickness of $27 \mathrm{~m}$. The thickness may increase towards the high.

The lithology of the reservoir unit in the $\mathrm{V}-1$ well is coarse-grained siltstone and fine-grained sandstone, moderately to poorly sorted due to a clay matrix, and 
locally very calcareous. Glauconite and pyrite are present.

The $\log$ porosity is $25 \%$ and seems high compared to visual estimates from sidewall cores. The clay and carbonate contents downgrade the reservoir potential.

The Ringk $\phi$ bing-Fyn High is presumed to have acted as a source area for the Vyl Formation (see the Poul Formation).

\section{Pelagic carbonates}

Pelagic carbonate reservoirs are well known features of North Sea geology, where one of the important reservoir rocks is the Upper Cretaceous Chalk Group.

The Lower Cretaceous sequence of the Danish Central Trough and the adjacent areas in the German, British and Norwegian sectors is characterized by clay deposits with upwards increasing carbonate content. This change from clastic influx to a dominance of pelagic carbonate deposition may be related to rising sea-level during sedimentation.

At mid Hauterivian to mid Barremian time, pelagic carbonates became the dominant sediment, and chalk of the Tuxen Formation was deposited (Jensen et al. 1986).

\section{Tuxen Formation}

This formation blankets the main part of the Central Trough. It consists of interbedded marlstone and chalk in the lower part and is terminated upwards by a thick chalk sequence. Only the chalk section is regarded as having reservoir potential.

The porosity in the chalk is fair, with an average of around $20 \%$. However, because of a clay content of 5 to $10 \%$ permeabilities are low. It is, therefore, necessary to find locations where processes, which have created conditions for higher porosity and particularly permeability, have been active. Resedimentation processes have been indicated as one of the mechanisms which may cause relatively better chalk reservoir qualities (cf. Hardman 1982, Nygaard et al. 1983). In the Lower Cretaceous chalk facies analyses on core samples from the Adda-2, E-1 and I-1 wells have shown the presence of debris flow deposits. Location of reworked chalk within the basin may be indicated by thickness variations. However, such locations have to be deduced from well data, as the thickness of the Tuxen Formation generally goes below seismic resolution (Jensen et al. 1986). 


\section{Concluding remarks}

The basinal analysis presented in this paper has emphasized the sedimentary development as controlled by the evolution of the structural pattern during the Jurassic and Early Cretaceous. The general trend in the sedimentation is deposition of fine-grained clastic material from the beginning of the Early Jurassic, with increasing production and preservation of organic material during the Late Jurassic. Deposition of fine-grained clastic sediments continued in the Early Cretaceous, but in an oxygenated environment from mid Ryazanian time, and with decreasing clastic influx.

This development was interrupted by various tectonic events creating hiati, unconformities and giving rise to the influx of coarse-grained deposits.

The so-called mid Cimmerian tectonic phase with uplift and subsequent erosion created the basis for deposition of sheet-like bodies of fluvial, deltaic and marginal marine sands. These are likely to be found in the main part of the Central Trough and represent a regionally rather uniform depositional regime which prevailed during the Middle Jurassic.

During the Late Jurassic the depositional environments varied from place to place in the Danish Central Trough. Oxfordian to Kimmeridgian, shallow marine sands were deposited around the Inge and Mads Highs, and similar sands may be present to the north around the Mandal High. Density current deposits may have occurred in the deeper parts of the basin.

Increasing Kimmeridgian and Volgian fault activity and subsidence resulted in deposition of large amounts of fine-grained clastic material, especially in the Tail End Graben. More coarse-grained clastic sediments which interfinger with the basinal, marine clay sequence was probably brought in by density currents. These latter deposits seem to be connected with the major boundary fault zone along the Ringkøbing-Fyn High. A similar environment of deposition may have prevailed along the corresponding fault zones of the Feda Graben, Gertrud Graben etc. This type of coarsegrained clastic deposition continued until the beginning of the Early Cretaceous. Turbiditic sediments were possibly deposited in the axial parts of the trough, probably by resedimentation from the Heno Plateau and from the highs to the west and north.

The decreasing tectonic activity during the Early Cretaceous created the background for a more uniform depositional regime. Clay with an increasing amount of carbonate was deposited. Thus the area evolved from graben subsidence to regional subsidence.

\section{Acknowledgements}

The work forming the basis for the present paper has been carried out as the concluding part of a project study financially supported by the Ministry of Energy. The late Prof. Tove Birkelund and Dr. Stefan Piasecki have provided great help and advice during the project work.

Prof. Finn Surlyk and Dr. Gunver Krarup Pedersen have carefully read the manuscript and suggested many improvements. Our heartiest thanks go to these colleagues and the members of the project group who have helped to increase the quality of the paper.

Dr. Richard Wilson is thanked for correcting the English manuscript. Mrs. Inge Martin-Legene, Mrs. Gitte Nicolaisen and Mrs. Helle Zetterwall have produced the drawings, Mrs. Pia Andersen and Mrs. Dorthe Plougmann typed the manuscript. 


\section{References}

Andersen, C.; Olsen, J.C.; Michelsen, O. \& Nygaard, E., 1982: Structural outline and development. In: Michelsen, O. (ed.): Geology of the Danish Central Graben. Danm. geol. Unders., Ser. B, 8, pp. 9-26.

Bailey, C.C., Price, I. \& Spencer, A.M., 1981: The Ula oil field, block 7/12, Norway. In: Norwegian Symposium on Exploration (NSE-81). Norsk Petroleumsforening, Bergen, pp. 1-21.

Bertelsen, F., 1980: Lithostratigraphy and depositional history of the Danish Triassic. Danm. geol. Unders., Ser. B, 4, 60 pp.

Birkelund, T., Clausen, C.K., Hansen, H.N. \& Holm, L., 1983: The Hectoroceras kochi Zone (Ryazanian) in the North Sea Central Graben and remarks on the Late Cimmerian Unconformity. Danm. geol. Unders., Årbog 1982, pp. 53-72.

Bjørlykke, K., Dypvik, H. \& Finstad, K.G., 1975: The Kimmeridgian shale, its composition and radioactivity. In: Finstad, K.G. \& Selley, R.C. (eds.): Jurassic Northern North Sea Symposium 1975. Norw. Petr. Soc., Stavanger, pp. 12: 1-20.

Damtoft, K., Andersen, C. \& Thomsen, E., 1987: Prospectivity and hydrocarbon plays of the Danish Central Trough. Proceedings from the 3rd Conference on Petroleum Geology of NW-Europe. Graham \& Trodman, London, (in press).

Eynon, G., 1981: Basin Development and Sedimentation in the Middle Jurassic of the Northern North Sea. In: Illing, L.V. \& Hobson, G.D. (eds.): Petroleum Geology of the Continental Shelf of North-west Europe. Inst. of Petroleum, London, pp. 196-204.

Frandsen, N., 1986: Middle Jurassic deltaic and coastal deposits in the Lulu-1 well of the Danish Central Trough. Danm. geol. Unders., Ser. A, 9, 23 pp.

Frandsen, N., Hoelstad, T. \& Mikkelsen, N., 1985: Middle Jurassic of the Danish Central Graben. In: Michelsen, O. (ed.): Symposium on Jurassic-Lower Cretaceous of the Central Graben, November 1984. Danm. geol. Unders., Internal rep. no. 6, pp. 6-19.

Gallois, R.W., 1976: Coccolith blooms in the Kimmeridge Clay and origin of North Sea Oil. Nature, 259, pp. 473-475.

Gowers, M.B. \& Sæbøe, A., 1985: On the structural evolution of the Central Trough in the Norwegian and Danish sectors of the North Sea. Marine and Petroleum Geology, 2, pp. 298-318.

Hallam, A., 1978: Eustatic cycles in the Jurassic. Palaeogeography, Palaeoclimatology, Palaeoecology, 23, pp. 1-32.

Hallam, A., 1981: A revised sea-level curve for the early Jurassic. J. geol. Soc. London, 138, pp. 735-743.

Hallam, A., 1984: Pre-Quaternary sea-level changes. Ann. Rev. Earth Planet. Sci., 1984, 12, pp. 205-243.

Hansen, J.M. \& Buch, A., 1982: Early Cretaceous. In: Michelsen, O. (ed.): Geology of the Danish Central Graben. Danm. geol. Unders., Ser. B, 8, pp. 45-49.

Hansen, J.M. \& Mikkelsen, N., 1983: Hydrocarbon geological aspects of subsidence curves; interpretations based on released wells in the Danish Central Graben. Bull. geol. Soc. Denmark, 31, pp. 159-169.

Hardmann, R.F.P., 1982: Chalk reservoirs of the North Sea. Bull. geol. Soc. Denmark, 30, pp. 119-137.

Heilmann-Clausen, C., 1987: Lower Cretaceous dinoflagellate biostratigraphy in the Danish Central Trough. Danm. geol. Unders., Ser. A, 17 (in press).

Hesjedal, A. \& Hamar, G.P., 1983: Lower Cretaceous stratigraphy and tectonics of the south-southeastern Norwegian offshore. In: Kaasschieter, J.P.H. \& Reijers, T.J.A. (eds.): Petroleum Geology of the southeastern North Sea and the adjacent onshore areas. Geol. Mijnbouw 62, pp. 135-144.

Hoelstad, T., 1986a: Palynology of the Middle Jurassic Lower Graben Sand Formation of the U-1 well, Danish Central Trough. Danm. geol. Unders., Ser. A, 14, 25 pp.
Hoelstad, T., 1986b: Palynology and palynofacies analyses of the Middle Jurassic to Lower Cretaceous in the Danish Central Trough. Danm. geol. Unders., Internal rep.

Holm, L., 1983: Subsidence history of the Jurassic sequence in the Danish Central Graben. Danm. geol. Unders., Årbog 1982, pp. 39-51.

Irwin, H., 1980: Early diagenetic carbonate precipitation and pore fluid migration in the Kimmeridge Clay of Dorset, England. Sedimentology, 27, pp. 577-591.

Jensen, T.F. \& Buchardt, B., 1987: Sedimentology and geochemistry of the organic carbon rich Lower Cretaceous Sola Formation (Barremian-Albian), Danish North Sea. Proceedings from the 3rd Conference on Petroleum Geology on NW-Europe. Graham \& Trodman, London, (in press).

Jensen, T.F., Holm. L., Frandsen, N. \& Michelsen, O., 1986: Jurassic-Lower Cretaceous lithostratigraphic nomenclature for the Danish Central Trough. Danm. geol. Unders., Ser. A, 12, 65 pp.

Johnson, H. D., Mackay, T.A. \& Stewart, D.J., 1986: The Fulmar Oil-field (Central North Sea): Geological aspects of its discovery, appraisal and development. Marine and Petroleum Geology, 3 , pp. 99-125.

Johnson, H.D. \& Steward, D.J., 1985: The role of clastic sedimentology in the exploration and production of oil and gas in the North Sea. In: Brenchley, P.J. \& Williams, B.P.J. (eds.): Sedimentology: Recent developments and applied aspects. Blackwells Scientific Publications, Oxford, pp. 249-310.

Kemper, E. \& Zimmerle, W., 1978: Die anoxischen Sedimente der praeoberaptischen Unterkreide NW-Deutschlands und ihr palaeogeographischer Rahmen. Geol. Jb., Rh. A, 45, pp. 3-41.

Kemper, E. \& Zimmerle, W., 1982: Das Ablagerungsmilieu zur Zeit des späten Apt und frühen Alb im Niedersächsischen Becken. Geol. Jb.,Rh. A, 65, pp. 655-680.

Kent, D.V. \& Gradstein, F.M., 1985: A Cretaceous and Jurassic geochronology. Geol. Soc. Am. Bull., 96, pp. 1419-1427.

Koch, J.-O., 1983: Sedimentology of Middle and Upper Jurassic sandstone reservoirs of Denmark. In: Kaasschieter, J.P.H. \& Reijers, T.J.A. (eds.): Petroleum geology of the southeastern North Sea and the adjacent onshore areas. Geol. Mijnbouw, 62, pp. 115-129.

Koch, J.-O., Holm, L. \& Michelsen, O., 1982: Jurassic. In: Michelsen, O. (ed.): Geology of the Danish Central Graben. Danm. geol Unders., Ser. B, 8, pp. 37-45.

Lindgreen, H., 1983: Mineralogical Investigation of the Jurassic Sandstone Reservoir of Lulu-1. Danm. geol. Unders., Internal rep.

Lindgreen, H., Thomsen, E. \& Wrang, P., 1982: Source rocks. In: Michelsen, O. (ed.): Geology of the Danish Central Graben. Danm. geol. Unders., Ser. B, 8, pp. 73-86.

Michelsen, O., 1978a: The Lower Jurassic of the Dansk Nords $\varnothing$ O-1 boring, Central Trough. Danm. geol. Unders., Årbog 1977, pp. $77-87$.

Michelsen, O., 1978b: Stratigraphy and distribution of Jurassic deposits of the Norwegian-Danish Basin. Danm. geol. Unders., Ser. B, 2, 35 pp.

Michelsen, O. (ed.), 1982: Geology of the Danish Central Graben. Danm. geol. Unders., Ser, B, 8, pp. 73-86.

Michelsen, O. \& Andersen, C., 1983: Mesozoic structural and sedimentary development of the Danish Central Graben. In: Kaasschieter, J.P.H. \& Reijers, T.J.A. (eds.): Petroleum geology of the southeastern North Sea and the adjacent onshore areas. Geol. Mijnbouw, 62, pp. 93-102.

Michelsen, O., Holm, L. \& Frandsen, N., 1984: Stratigraphy of the Danish Jurassic sequence. Internation. Symp. Jur. Strat., Erlangen, pp. 755-766. 
Møller, J.J., 1986: Seismic structural mapping of the Middle and Upper Jurassic in the Danish Central Trough. Danm. geol. Unders., Ser. A, 13, 37 pp.

NAM \& RGD (Nederlandse Aardolie Maatschappij B.V. \& Rijks Geologische Dienst), 1980: Stratigraphic nomenclature of the Netherlands. Verh. Koninkl. Nederl. Geol. Mijnbouwkund. Genootsch., 32, 77 pp.

Nygaard, E., Lieberkind, K. \& Frykman, P., 1983: Sedimentology and reservoir parameters of the Chalk Group in the Danish Central Graben. In: Kaasschieter, J.P.H. \& Reijers, T.J.A. (eds.) Petroleum geology of the southeastern North Sea and the adjacent onshore areas. Geol. Mijnbouw, 62, pp. 177-190.

Poulsen, N., 1986: Callovian-Volgian dinocyst-stratigraphy of the Central Trough in the Danish North Sea area. Bull. geol. Soc. Denmark, 35, 10 pp.

Poulsen, N., 1987: Callovian (Jurassic) to Ryazanian (Cretaceous) dinoflagellate biostratigraphy of the Danish Central Trough. Danm. geol. Unders., Ser. A, (in prep.).

Rasmussen, L.B., 1974: Some geological results from the first five Danish exploration wells in the North Sea. Danm. geol. Unders., III rk., 42, $46 \mathrm{pp}$.

Rasmussen, L.B., 1978: Geological aspects of the Danish North Sea sector. Danm. geol. Unders., III rk., 44, 85 pp.

Rawson, P.F. \& Riley, L.A., 1982: Latest Jurassic-Early Cretaceous events and the Late Cimmerian Unconformity in the North Sea area. AAPG Bull., 66, pp. 2628-2648.

Rhys, G.H. (compiler), 1974: A proposed standard lithostratigraphic nomenclature for the southern North Sea and an outline structural nomenclature for the whole of the (UK) North Sea. Rep. Inst. Geol. Sci., 74/8, 14 pp.

Ryan, W.B.F. \& Cita, M.B., 1977: Ignorance concerning episodes of ocean-wide stagnation. Marine Geology, 23, pp. 197-215.

Schlanger, S.O. \& Jenkyns, H.C., 1976: Cretaceous anoxic events: Causes and consequences. Geol. Mijnbouw, 55 (3-4), pp. 179-184.
Stow, D.A.V., Howell, D.G. \& Nelson, C.H., 1984: Sedimentary, tectonic, and sea-level controls on submarine fan and slope apron turbidite systems. Geo-Marine Letters, 3, pp. 57-64.

Thomsen, E., 1987: Lower Cretaceous calcareous nannofossil biostratigraphy in the Danish Central Trough. Danm. geol. Unders., Ser. A, 20 (in prep.).

Thomsen, E., Lindgreen, H. \& Wrang, P., 1983: Investigation on the source rock potential of Denmark. In: Kaasschieter, J.P.H. \& Reijers, T.J.A. (eds.): Petroleum geology of the southeastern North Sea and the adjacent onshore areas. Geol. Mijnbouw, 62, pp. 221-239.

Tyson, R.V., Wilson, R.C.L. \& Downie, C., 1979: A stratified water column environmental model for the type Kimmeridge Clay. Nature, 277, pp. 377-380.

Vail, P.R. \& Todd, R.G., 1981: Northern North Sea Jurassic Unconformities, Chronostratigraphy and Sea-level Changes from Seismic Stratigraphy. In: Illing, L.V. \& Hobson, G.D. (eds.): Petroleum Geology of the Continental Shelf of North-west Europe. Inst. of Petroleum, London, pp. 216-235.

Vejbæk, O.V., 1986: Seismic stratigraphy of the Lower Cretaceous in the Danish Central Trough. Danm. geol. Unders., Ser. A, 11, 46 pp.

Vollset, J. \& Doré, A.G. (eds.), 1984: A revised Triassic and Jurassic lithostratigraphic nomenclature for the Norwegian North Sea. NPD Bull. 3, Stavanger, $53 \mathrm{pp}$.

Ziegler, P.A., 1982: Geological Atlas of Western and Central Europe. Elsevier Scientific Publishing Company, Amsterdam. 130 pp.

Østfeldt, P., 1987: Oil source rock correlation in the Danish North Sea. Proceedings from the 3rd Conference on Petroleum Geology of NW-Europe. Graham \& Trodman, London (in press). 
This paper comprises a compilation of the results from the research project on the Jurassic and Lower Cretaceous sequences of the Danish Central Trough.

A revised model for the basin development is described on the basis of new studies of bio- and lithostratigraphy and sedimentological and seismic data. Distribution and character of possible reservoir bodies are discussed. 